University of Nebraska - Lincoln DigitalCommons@University of Nebraska - Lincoln

USGS Staff -- Published Research

US Geological Survey

2002

\title{
Organochlorine Chemical Residues in Fish from the Mississippi River Basin, 1995
}

C.J.Schmitt

United States Geological Survey, cjschmitt@usgs.gov

Follow this and additional works at: http:// digitalcommons.unl.edu/usgsstaffpub

Part of the Geology Commons, Oceanography and Atmospheric Sciences and Meteorology Commons, Other Earth Sciences Commons, and the Other Environmental Sciences Commons

Schmitt, C.J., "Organochlorine Chemical Residues in Fish from the Mississippi River Basin, 1995" (2002). USGS Staff -- Published Research. 940.

http:// digitalcommons.unl.edu/usgsstaffpub/940

This Article is brought to you for free and open access by the US Geological Survey at DigitalCommons@University of Nebraska - Lincoln. It has been accepted for inclusion in USGS Staff -- Published Research by an authorized administrator of DigitalCommons@University of Nebraska - Lincoln. 


\title{
Organochlorine Chemical Residues in Fish from the Mississippi River Basin, 1995
}

\author{
C. J. Schmitt \\ U.S. Geological Survey, Columbia Environmental Research Center, 4200 New Haven Rd., Columbia, Missouri 65201, USA
}

Received: 19 June 2001/Accepted: 19 January 2002

\begin{abstract}
Fish were collected in late 1995 from 34 National Contaminant Biomonitoring Program (NCBP) stations and 13 National Water Quality Assessment Program (NAWQA) stations in the Mississippi River basin (MRB) and in late 1996 from a reference site in West Virginia. Four composite samples, each comprising (nominally) 10 adult common carp (Cyprinus carpio) or black bass (Micropterus spp.) of the same sex, were collected from each site and analyzed for organochlorine chemical residues by gas chromatography with electron capture detection. At the NCBP stations, which are located on relatively large rivers, concentrations of organochlorine chemical residues were generally lower than when last sampled in the mid-1980s. Residues derived from DDT (primarily $p, p^{\prime}$-DDE) were detected at all sites (including the reference site); however, only traces $(\leq 0.02 \mu \mathrm{g} / \mathrm{g})$ of the parent insecticide $\left(p, p^{\prime}-\right.$ DDT) were present, which indicates continued weathering of residual DDT from past use. Nevertheless, concentrations of DDT (as $p, p^{\prime}$-DDE) in fish from the cotton-farming regions of the lower MRB were great enough to constitute a hazard to fish-eating wildlife and were especially high at the NAWQA sites on the lower-order rivers and streams of the Mississippi embayment. Mirex was detected at only two sites, both in Louisiana, and toxaphene was found exclusively in the lower MRB. Most cyclodiene pesticides (dieldrin, chlordane, and heptachlor epoxide) were more widespread in their distributions, but concentrations were lower than in the 1980s except at a site on the Mississippi River near Memphis, TN. Concentrations were also somewhat elevated at sites in the Corn Belt. Endrin was detected exclusively at the Memphis site. PCB concentrations generally declined, and residues were detected $(\geq 0.05 \mu \mathrm{g} / \mathrm{g})$ at only $35 \%$ of the stations, mostly in the more industrialized parts of the MRB.
\end{abstract}

Environmental concentrations of organochlorine pesticides, polychlorinated biphenyls (PCBs), and other persistent environmental contaminants have generally declined over the last two decades (Schmitt and Bunck 1995; Schmitt et al. 1999c; Gundersen et al. 2000). In North America and elsewhere the release of many such contaminants to the environment has been reduced or eliminated through regulation and replacement by shorter-lived, less toxic compounds. Nevertheless, there is a substantial body of information indicating that concentrations of accumulative contaminants in fish may remain sufficiently elevated to harm fish and wildlife in some areas (e.g., Gooch and Matsamura 1987; Colborn 1991; Tillitt et al. 1992; Schmitt et al. 1999c), and concentrations of some contaminants may be increasing in the Arctic (e.g., Muir et al. 1999). In addition to continuing incidents of wildlife mortality attributable to persistent, obsolete pesticides (e.g., Stansley and Roscoe 1999), reports of reproductive impairment (see reviews by Colborn et al. [1993] and Sumpter et al. [1996]), immune system dysfunction (Blazer and Dethloff 2000), and other health problems in fish and wildlife has maintained interest in organochlorine chemicals. Accordingly, concentrations of accumulative contaminants in fish has been proposed as an indicator of sustainable economic development (CEQ 1997), and periodic measurement of these concentrations is an integral part of many environmental monitoring programs (Hirsch et al. 1988; Messer et al. 1991; BEST 1996; Wong et al. 2000).

This article summarizes one component of a larger investigation conducted in 1995-96 (Schmitt and Dethloff 2000) that included both chemical and biological components. The report is intended to provide contemporary information on the distribution, concentrations, and ecological risks of organochlorine chemical residues in fish of the Mississippi River basin (MRB), where contaminants in fish had not been evaluated comprehensively since the mid-1980s (Schmitt et al. 1999c). The 1995 results are compared with other contemporary studies and with previous NCBP findings and are evaluated relative to extant information on ecological risk. The larger study was a pilot for a national monitoring program incorporating biological and chemical indicators (Schmitt et al. 1999a, 1999b). In addition to the results reported here the study included measurement of elemental contaminant concentrations and biomarkers of chemical exposure and their effects. The overall approach being evaluated was the use of readily available and comparatively inexpensive methods as a first-tier screen, with costlier, higherresolution methods reserved for follow-up investigations based on tier 1 results. In addition to cost-effectiveness and compatibility with the biological endpoints of the larger investigation (Schmitt et al. 1999a; Schmitt and Dethloff 2000), analytical methods were also chosen because of their similarity to those used in the past (Schmitt et al. 1999c) for evaluating temporal 
trends. Raw data for the entire study, as well as 1969-1986 NCBP data, may be obtained online at www.cerc.usgs.gov/ data/data.htm.

\section{Materials and Methods}

\section{Study Area and Collection Sites}

The MRB drains all or parts of 32 states (about $41 \%$ of the conterminous United States) and parts of two Canadian provinces (Figure 1) and has a human population of more than 72 million. Agricultural development in the MRB is extensive, accounting for $>50 \%$ of U.S. corn, wheat, soybean, cattle, and hog production (Goolsby 1996). There is also substantial urban, industrial, and mining development. Consequently, many programs and studies (e.g., Thurman et al. 1991; Goolsby et al. 1993; Ellis et al. 1995; Meade 1995; Schmitt et al. 1999c; Wong et al. 2000) have documented the presence and widespread distribution of numerous contaminants of agricultural, industrial, and mining origin in the Mississippi River and its tributaries, as well as the export of nutrients and contaminants to the Gulf of Mexico (Trefry et al. 1985; Meade 1995; Rostad 1997). Information on contaminants in the large rivers of the MRB needed to be updated because substantial quantities of pesticides and other materials were redistributed and transported out of the basin by extreme flooding in 1993 and 1995 (Rostad 1997).

Fish were collected in late 1995 from 34 of the 38 National Contaminant Biomonitoring Program (NCBP) stations in the MRB (Figure 1, Table 1) and analyzed for organochlorine chemical residues (Table 2). Two NCBP sites in the upper Platte River system were not sampled because organochlorine chemicals had been extensively investigated there in 1992-93 (Tate and Heiny 1996). At the NCBP stations, which represent key points (i.e., confluences of major tributaries, impoundments) on some of the largest U.S. rivers, concentrations of accumulative contaminants in fish were monitored from 1967 through 1986 (Johnson et al. 1967; Schmitt and Bunck 1995; Schmitt et al. 1999c). Fish were also collected in 1995 at 13 National Water Quality Assessment Program (NAWQA) sites-9 in the Mississippi Embayment (MSE) Study Unit (Mallory 1994) and 4 in the Eastern Iowa Basins (EIB) Study Unit (Kalkhoff et al. 1994; Figure 1, Table 1). The NAWQA sites typically represent lower-order rives and streams than the NCBP sites. Because all the NCBP and NAWQA sites in the MRB are contaminated to some degree, samples were also collected in late 1996 from the water supply reservoirs of the USGS Leetown Science Center in Kearneysville, WV (reference site) to better document contemporary background conditions.

\section{Field Procedures}

Fish were captured by electrofishing and held alive until needed for processing (generally $<4 \mathrm{~h}$ ). At each NCBP site, a total of 40 adult fish representing two taxa-common carp (Cyprinus carpio, hereafter "carp") and black basses (Micropterus spp., "bass")—were sought, with the target being 10 males and 10 females of each species. Alternate bottom-dwelling and piscivorous species were permitted as necessary. At the NAWQA stations only carp (10 males, 10 females) were collected at 11 sites, only largemouth bass (M. salmoides) were collected at 1 site, and both species were collected at 1 site. These taxa were selected because they had been prevalent in past NCBP and NAWQA collections (Crawford and Luoma 1992; Schmitt et al. 1999c) and because the biological endpoints measured in other components of the study had been most thoroughly tested in them (Schmitt et al. 1999b; Schmitt and Dethloff 2000). Fish were processed as described by Schmitt et al. (1999b). In short, each fish was measured, weighed, and placed on a clean sheet of aluminum foil. The abdominal cavity was dissected open and gender was determined by gonadal observation. Samples of blood, liver, kidney, scales, and spleen were obtained for other analyses (Schmitt et al. 1999a). After processing, all remaining tissues were returned to the carcass, which was wrapped in the foil on which it was processed, labeled, and chilled. Carcass samples comprised whole fish minus approximately $5 \mathrm{ml}$ of blood, five to eight $1-\mathrm{cm}^{3}$ pieces of liver, five $1-\mathrm{cm}^{3}$ gonad pieces, the entire spleen, 5-10 scales, and a $1-\mathrm{cm}^{3}$ piece of both the posterior and anterior kidneys. The total mass of tissues not included in the carcass analyses represented $<1 \%$ of the original mass of each fish. Between samples all contact surfaces and instruments were thoroughly cleaned with tap water and rinsed with deionized water and acetone. After all sampling at a station was completed, fish were frozen $\left(-20^{\circ} \mathrm{C}\right)$ and shipped to the analytical laboratory, where they were kept frozen until prepared for analysis.

\section{Laboratory Analyses}

Chemical analyses were performed by contract laboratories under the supervision of the U.S. Fish and Wildlife Service (FWS) Patuxent Analytical Control Facility (PACF) in Laurel, MD, which maintained quality assurance (Q/A) oversight. For compatibility with other aspects of the larger study (Schmitt et al. 1999a; Schmitt and Dethloff 2000), samples from each station were composited by species and gender. Individual fish were first band-sawed into pieces after which all the pieces of all the fish in the sample being prepared were ground together three times with a commercial meat grinder. A 10-g subsample was retained for gravimetric determination of lipid content and analysis of organochlorine chemical residues by gas chromatography with electron capture detection (GC-ECD). Additional aliquots were retained for $\mathrm{Q} / \mathrm{A}$ and for analyses not reported here. Between samples all equipment was disassembled, washed in hot soapy water, and rinsed with water, acetone, and petroleum ether. The 10-g subsamples of ground fish were mixed with anhydrous sodium sulfate, Soxhletextracted with hexane for $7 \mathrm{~h}$, and concentrated by rotary evaporation. The concentrated samples were transferred to tared test tubes and evaporated to constant weight to estimate lipid content. After weighing, the lipid samples were redissolved in $12 \mathrm{ml}$ petroleum ether (in three washes of 5,4 , and $3 \mathrm{ml}$ ), then extracted four times with $30 \mathrm{ml}$ (each) of acetonitrile saturated with petroleum ether. Residues in this extract were partitioned into petroleum ether, concentrated to 4-5 ml by Kuderna-Danish, and transferred to glass chromatographic columns containing $20 \mathrm{~g}$ of Florisil ${ }^{\circledR}$. The Florisil was eluted with $200 \mathrm{ml} 6 \%$ diethyl ether in petroleum ether (F-I) followed by $200 \mathrm{ml} 15 \%$ diethyl ether in petroleum ether (F-II). Both fractions were concentrated to 10 $\mathrm{ml}$. F-II was analyzed for polar insecticide residues by dual megaborecolumn GC-ECD. F-I was transferred to a glass column $(40 \mathrm{~mm} \times 1$ $\mathrm{cm}$ ID with a 14- $\times 4$-cm ID reservoir on top) containing $5 \mathrm{~g}$ of silicic acid (Mallinckrodt 7068 , activated at $130^{\circ} \mathrm{C}$ for $\geq 7$ days), from which three fractions were eluted: SA-I (20 ml of petroleum ether) contained hexachlorobenzene (HCB) and mirex; SA-II $(150 \mathrm{ml}$ of petroleum ether) contained PCBs; and SA-III (20 ml of 1:19:80 acetonitrile: hexane:methylene chloride) contained organochlorine pesticides. Each of these fractions was concentrated to $10 \mathrm{ml}$ for megabore-column GC-ECD using dual DB-608 and DB-5 (30-m $\times$ 0.52-mm ID) columns, with the injection split between the columns and routed to two detectors. Temperatures were injector, $220^{\circ} \mathrm{C}$; detector, $300^{\circ} \mathrm{C}$; and column, $160^{\circ} \mathrm{C}$ for $5 \mathrm{~min}$, increased $2^{\circ} \mathrm{C} / \mathrm{min}$ to $210^{\circ} \mathrm{C}$ for $8 \mathrm{~min}$, then increased $5^{\circ} \mathrm{C} / \mathrm{min}$, to $230^{\circ} \mathrm{C}$ for $4 \mathrm{~min}$. The make-up gas was $\mathrm{N}_{2}$, and the carrier gas was $\mathrm{H}_{2}$. PCB residues in SA-II were quantified against $1-\mu 1$ injections of $0.5-\mathrm{ng} / \mu 1$ Aroclor $1242,1248,1254$, and 1260 standards. Starting with Aroclor 1260, four peaks unique to this mixture were located and their areas summed. The same peaks in 




Fig. 1. Map of the central United States showing the Mississippi River Basin (shaded area) and the stations sampled in 1995 (1996 for Station 400). See Table 1 for river names and station locations the sample were also located and summed, and Aroclor 1260 (in $\mu \mathrm{g} / \mathrm{g}$ wet weight) was estimated as [(sample area)(ng 1260 standard)] / [(standard area)(mg sample extracted)]. Aroclor 1254 was also estimated by locating the major peaks (typically four) in the mixture that are normally found in environmental samples. The areas of these peaks were summed, but because some this area also represents Aroclor 1260 the 1260 contribution was subtracted from the total area: [(sample area)-[( $\mu \mathrm{g} / \mathrm{g} 1260)(\mathrm{mg}$ sample extracted)(area from 1260)(ng 1260 standard)](ng 1254 standard)] / [(area 1254 standard)(mg sample extracted)]. Aroclor 1248 was estimated similarly, after accounting for both 1260 and 1254. Aroclor 1242 was quantified using the area of five early eluting peaks present in the standard. Total PCB was reported as the sum of the four Aroclor mixtures estimated per above. Toxaphene residues in SA-III were quantified using the areas of five to six peaks present in both the samples and standards. The nominal limit of detection (LOD) for individual compounds was $0.01 \mu \mathrm{g} / \mathrm{g}$ wet weight, and for toxaphene and total PCBs it was $0.05 \mu \mathrm{g} / \mathrm{g}$. As previously (Schmitt et al. $1999 \mathrm{c}$ ), analytical results were not adjusted to reflect spike recoveries or moisture loss during storage

Precision and accuracy of laboratory results were confirmed through analyses of procedural blanks, duplicates, fortified samples, and reference materials. Duplicate analyses $(n=9)$ typically differed by $3-5 \%$ except for total PCBs (9\%). Mean recovery efficiency of fortified samples ( $\mathrm{n}=9$ ) was $92-104 \%$ except for dieldrin $(88 \%)$ and $\mathrm{HCB}$ (70\%). The identities of residues were confirmed by gas chromatography/mass spectrometry (GC/MS) in about $10 \%$ of the samples with a Varian Saturn 2000 ion-trap MS, positive EI mode, on a 30-m $\times$ 0.25-mm (ID) DB-5 capillary column and a Model 1078 injector (14 psi head pressure, trap $235^{\circ} \mathrm{C}$, manifold $50^{\circ} \mathrm{C}$, transfer line $285^{\circ} \mathrm{C}$ ). Injector temperature was $300^{\circ} \mathrm{C}$. Column temperatures were $40^{\circ} \mathrm{C}$ for $2 \mathrm{~min}$; increase $25^{\circ} \mathrm{C} / \mathrm{min}$ to $150^{\circ} \mathrm{C}$; increase $4^{\circ} \mathrm{C} / \mathrm{min}$ to $290^{\circ} \mathrm{C}$; hold 3.6 min. Round-robin tests among PACF and contract laboratories were also conducted.

\section{Data Set Composition and Statistical Analyses}

A total of 164 composite samples from 46 stations (including the reference site) were analyzed. Of these, 89 samples (54\%) from 45 stations (96\%) were carp and 58 (35\%) from 30 stations (64\%) were bass-largemouth, smallmouth (Micropterus dolomieui), and spotted (M. punctulatus). The remaining 17 samples (11\%) comprised white suckers (Catostomus commersoni; two samples from one station), white bass (Morone chrysops; four samples, two stations), sauger (Stizostedion canadense; three samples, two stations), brown trout (Salmo trutta; two samples, one station), goldeye (Hiodon alosoides; two samples, one station), smallmouth buffalo (Ictiobus bubalus; two samples, one station), and northern pike (Esox lucius; one sample, one station). At most NCBP stations there was at least one species common to both the 1995 and 1986 collections (Schmitt et al. 1999c) for the examination of withintaxon temporal trends.

Concentrations of most organochlorine chemical residues were below the LOD in many samples (Table 2), which precluded rigorous statistical analysis. As in the past (Schmitt et al. 1999c), a value of one-half the LOD was substituted for the censored values in the computation of unweighted geometric species, sex, and station means, which introduces relatively little bias (US EPA 2000). Because temporal and geographic comparisons are readily confounded by differences among taxa (Schmitt et al. 1999c), within-taxon comparisons were made where possible. Only for $p, p^{\prime}$-DDE were there sufficient numbers of uncensored observations in both carp and bass for statistical testing. For geographic analysis stations were aggregated by subbasin and program (NCBP vs. NAWQA-Table 1). The MSE and EIB Study Units are wholly contained within the Lower Mississippi River and Upper Mississippi River subbasins, respectively (Figure 1, Table 1). Therefore, comparisons of these subbasins represent regional contrasts of large-river stations against those on lower-order rivers and 
Table 1. Locations of National Contaminant Biomonitoring Program (NCBP) and National Water Quality Assessment Program (NAWQA) stations in the Mississippi River basin (sampled in 1995) and of the reference site (sampled in 1996)

\begin{tabular}{|c|c|c|c|c|}
\hline $\begin{array}{l}\text { Program, Subbasin (NCBP) or } \\
\text { Study Unit (NAWQA) and } \\
\text { Station Number }\end{array}$ & River & Nearest City or Feature & $\begin{array}{l}\text { Latitude } \\
\text { (dd-mm-ss) }\end{array}$ & $\begin{array}{l}\text { Longitude } \\
\text { (dd-mm-ss) }\end{array}$ \\
\hline \multicolumn{5}{|l|}{ NCBP } \\
\hline \multicolumn{5}{|l|}{ Arkansas-Red R. (ARR) } \\
\hline 29 & Arkansas & Keystone Res., OK & $36-07-54.0$ & $96-20-47.0$ \\
\hline 77 & Arkansas & John Martin Res., CO & $38-03-55.0$ & $102-56-02.0$ \\
\hline 78 & Verdigris & Oolagah, OK & $36-31-16.0$ & $95-33-37.0$ \\
\hline 79 & Canadian & Eufaula, OK & $35-16-43.0$ & $95-34-39.0$ \\
\hline 82 & Red & Lake Texoma, TX/OK & $33-52-08.0$ & $96-47-04.0$ \\
\hline \multicolumn{5}{|l|}{ Lower Missouri R. (LMO) } \\
\hline 31 & Missouri & Nebraska City, NE & $40-40-15.9$ & $95-49-44.6$ \\
\hline 83 & Missouri & Hermann, MO & $38-42-24.1$ & $91-26-17.5$ \\
\hline 86 & James & Olivet, SD & $43-13-45.0$ & $97-41-05.0$ \\
\hline 89 & Platte & Louisville, NE & $40-59-33.1$ & $96-12-30.9$ \\
\hline 90 & Kansas & Bonner Springs, KS & $39-02-47.0$ & $94-47-05.0$ \\
\hline \multicolumn{5}{|l|}{ Upper Missouri R. (UMO) } \\
\hline 32 & Missouri & Garrison Dam, ND & $47-28-27.3$ & $101-26-15.5$ \\
\hline 84 & Big Horn & Hardin, MT & $45-52-12.2$ & $107-34-34.0$ \\
\hline 85 & Yellowstone & Sidney, NE & $47-34-46.8$ & $104-13-10.7$ \\
\hline \multicolumn{5}{|l|}{ Lower Mississippi R. (LMR) } \\
\hline 15 & Mississippi & Luling, LA & $29-59-53.2$ & $90-25-31.1$ \\
\hline 28 & Arkansas & Pine Bluff, AR & $34-16-27.0$ & $94-57-12.0$ \\
\hline 30 & White & Devall's Bluff, AR & $34-47-01.0$ & $91-26-28.0$ \\
\hline 75 & Mississippi & Cape Girardeau, MO & $37-18-36.0$ & $89-31-01.2$ \\
\hline 76 & Mississippi & Memphis, TN & $38-08-30.3$ & $90-03-36.6$ \\
\hline 80 & Yazoo & Redwood, MS & $32-24-36.0$ & $90-55-27.0$ \\
\hline 81 & Red & Alexandria, LA & $31-20-48.0$ & $92-27-37.0$ \\
\hline \multicolumn{5}{|l|}{ Upper Mississippi R. (UMR) } \\
\hline 26 & Illinois & Beardstown, IL & $40-07-50.6$ & $90-20-45.6$ \\
\hline 27 & Mississippi & Guttenburg, IA & $42-43-37.2$ & 91-01-30.0 \\
\hline 72 & Wisconsin & Woodman, WI & $43-05-42.0$ & $90-48-57.6$ \\
\hline 73 & Des Moines & Keosauqua, IA & $40-44-52.8$ & $91-59-38.4$ \\
\hline 74 & Mississippi & Little Falls, MN & $45-58-48.0$ & $94-22-00.0$ \\
\hline 111 & Mississippi & Lake City, MN & $44-22-49.8$ & $92-07-33.0$ \\
\hline 112 & Mississippi & Dubuque, IA & $42-26-27.6$ & $90-35-06.0$ \\
\hline \multicolumn{5}{|l|}{ Ohio R. (OHR) } \\
\hline 23 & Kanawha & Winfield, WV & $38-29-06.0$ & $81-48-57.6$ \\
\hline 24 & Ohio & Marietta, $\mathrm{OH}$ & $39-24-36.8$ & $81-26-26.3$ \\
\hline 25 & Cumberland & Clarksville, $\mathrm{OH}$ & $36-32-28.6$ & $87-22-04.7$ \\
\hline 67 & Allegheny & Natrona, PA & $40-39-54.0$ & $79-41-24.0$ \\
\hline 68 & Wabash & New Harmony, IN & $38-11-58.4$ & $87-58-36.0$ \\
\hline 70 & Ohio & Metropolis, IL & $37-07-40.8$ & $88-39-25.2$ \\
\hline 71 & Tennessee & Savannah, TN & $35-12-52.0$ & $88-18-36.0$ \\
\hline \multicolumn{5}{|l|}{ NAWQA } \\
\hline \multicolumn{5}{|l|}{ Eastern Iowa Basins (EIB) } \\
\hline 205 & S. Skunk & Oskaloosa, IA & $41-21-19.0$ & $92-39-31.0$ \\
\hline 206 & Iowa & Morengo, IA & $41-50-23.0$ & $92-11-54.0$ \\
\hline 209 & S. Fork Iowa & New Providence, IA & $42-19-26.0$ & $93-10-10.0$ \\
\hline 210 & Iowa & Rowan, IA & $42-45-36.0$ & $93-37-23.0$ \\
\hline 211 & Cedar & St. Charles City, IA & $43-03-45.0$ & $92-40-23.0$ \\
\hline \multicolumn{5}{|l|}{ Mississippi Embayment (MSE) } \\
\hline 201 & Big Sunflower & Anguilla, MS & $32-58-18.0$ & $90-46-40.0$ \\
\hline 202 & Bogue Phalia & Leland, MS & $33-24-22.0$ & $90-50-26.0$ \\
\hline 203 & Steele Bayou & Rolling Fork, MS & $32-54-71.0$ & $90-57-10.0$ \\
\hline 204 & Tensas & Tendal, LA & $32-25-56.0$ & $91-21-57.0$ \\
\hline 207 & Cache & Cotton Plant, AR & $35-02-32.0$ & $91-19-12.0$ \\
\hline 208 & Cache & Egypt, AR & $35-51-23.0$ & $90-56-15.0$ \\
\hline 212 & Little R. Ditch & Moorehouse, MO & $36-50-03.0$ & $89-43-48.0$ \\
\hline 213 & Wolf & LaGrange, TN & $35-01-57.0$ & $89-14-48.0$ \\
\hline \multicolumn{5}{|l|}{ Reference site } \\
\hline 400 & Leetown Res. & Kearneysville, WV & $39-21-2.2$ & $77-55-32.69$ \\
\hline
\end{tabular}


Table 2. Occurrence (percentages of samples and stations, including the reference site) and limits of detection (LOD) of organochlorine chemical residues in composite samples of whole fish (also shown are maximum concentrations and the sample [station, sex, and species] in which they occurred)

\begin{tabular}{|c|c|c|c|c|c|c|c|}
\hline \multirow[b]{2}{*}{ Analyte(s) } & \multirow{2}{*}{$\begin{array}{l}\text { Samples } \\
(\% \text { of } 163)\end{array}$} & \multirow{2}{*}{$\begin{array}{l}\text { Stations } \\
(\% \text { of } 46)\end{array}$} & \multirow[b]{2}{*}{ LOD $(\mu \mathrm{g} / \mathrm{g})$} & \multicolumn{4}{|c|}{ Maximum 1995 Concentrations } \\
\hline & & & & Conc. $(\mu \mathrm{g} / \mathrm{g})$ & Station & $\operatorname{Sex}$ & Species \\
\hline$p, p^{\prime}-\mathrm{DDT}^{1}$ & 8 & 15 & 0.01 & 0.14 & 24 & $\mathrm{~F}$ & Common carp \\
\hline$p, p^{\prime}-\mathrm{DDD}(\mathrm{TDE})^{2}$ & 58 & 74 & 0.01 & 2.80 & 201 & M & Common carp \\
\hline$p, p^{\prime}-\mathrm{DDE}^{3}$ & 91 & 100 & 0.01 & 8.30 & 201 & M & Common carp \\
\hline Total $p, p^{\prime}$-homologs & 91 & 100 & 0.01 & 11.10 & 201 & M & Common carp \\
\hline$o, p^{\prime}-\mathrm{DDT}^{4}$ & 3 & 4 & 0.01 & 0.24 & 24 & $\mathrm{~F}$ & Common carp \\
\hline$o, p^{\prime}-\mathrm{DDD}(\mathrm{TDE})^{5}$ & 12 & 24 & 0.01 & 0.34 & 24 & $\mathrm{~F}$ & Common carp \\
\hline$o, p^{\prime}-\mathrm{DDE}^{6}$ & 1 & 2 & 0.01 & 0.02 & 24 & $\mathrm{~F}$ & Common carp \\
\hline Dieldrin $^{7}$ & 42 & 57 & 0.01 & 0.25 & 76 & $\mathrm{~F}$ & Common carp \\
\hline Endrin $^{8}$ & 2 & 2 & 0.01 & 0.70 & 76 & $\mathrm{~F}$ & Common carp \\
\hline cis-Chlordane $^{9}$ & 37 & 48 & 0.01 & 0.12 & 76 & $\mathrm{~F}$ & Common carp \\
\hline trans-Chlordane $\mathrm{e}^{10}$ & 9 & 30 & 0.01 & 0.35 & 76 & $\mathrm{~F}$ & Common carp \\
\hline cis-Nonachlor $^{11}$ & 21 & 35 & 0.01 & 0.05 & 23 & $\mathrm{~F}$ & $\begin{array}{l}\text { Smallmouth } \\
\text { buffalo }\end{array}$ \\
\hline trans-Nonachlor $^{12}$ & 51 & 70 & 0.01 & 0.31 & 23 & $\mathrm{M}$ & Spotted bass \\
\hline Oxychlordane $^{13}$ & 6 & 9 & 0.01 & 0.03 & 76 & $\mathrm{~F}$ & Common carp \\
\hline Heptachlor epoxide ${ }^{14}$ & 9 & 15 & 0.01 & 0.08 & 206 & M & Common carp \\
\hline $\begin{array}{l}\text { Total chlordane- } \\
\text { related residues }\end{array}$ & 51 & 70 & 0.01 & 0.54 & 76 & $\mathrm{~F}$ & Common carp \\
\hline Toxaphene & 7 & 11 & 0.05 & 8.3 & 201 & M & Common carp \\
\hline $\operatorname{Mirex}^{16}$ & 4 & 4 & 0.01 & 0.08 & 204 & M & Common carp \\
\hline $\begin{array}{l}\text { Hexachlorobenzene } \\
(\mathrm{HCB})^{17}\end{array}$ & 2 & 7 & 0.01 & 0.07 & 24 & $\mathrm{M}$ & Common carp \\
\hline Total PCBs & 21 & 35 & 0.05 & 3.3 & 24 & $\mathrm{M}$ & Common carp \\
\hline $\begin{array}{l}\text { Hexachlorocylohexane } \\
(\mathrm{HCH})^{18}\end{array}$ & 0 & 0 & 0.01 & 0 & - & - & - \\
\hline
\end{tabular}

See Table 1 for station locations.

ND, not detected.

${ }^{1}$ 2,2-bis ( $p$-Chlorophenyl)-1,1,1-trichloroethane

${ }^{2}$ 2,2-bis ( $p$-Chlorophenyl)-1,1-dichloroethane

${ }^{3}$ 2,2-bis ( $p$-Chlorophenyl)-1,1-dichloroethylene

${ }^{4}$ 2-(o-Chlorophenyl)-2-(p-chlorophenyl)-1,1,1-trichloroethane

${ }^{5}$ 2-(o-Chlorophenyl)-2-( $p$-chlorophenyl)-1,1-dichloroethane

${ }^{6}$ 2-(o-Chlorophenyl)-2( $p$-chlorophenyl)-1,1-dichloroethylene

7 1,2,3,4,10,10-Hexachloro-6,7-epoxy-1,4,4a,5,8,8a-hexahydro-1,4-endo-exo-5,8-dimethanonaphthalene

8 1,2,3,4,10,10-Hexachloro-6,7-epoxy-1,4,4a,5,6,7,8,8a-octahydro-1,4-endo-endo-5,8-dimethanonaphthalene

9 1,2,4,5,6,7,8,8-Octachloro-2,3,3a,4,7,7a-hexahydro-4,7-methano- $1 \mathrm{H}$-indene $(1-\alpha, 2-\alpha, 3 \mathrm{a}-\alpha, 4-\beta, 7-\beta, 7 \mathrm{a}-\alpha)$

${ }_{10} 1,2,4,5,6,7,8,8$-Octachloro-2,3,3a,4,7,7a-hexahydro-4,7-methano-1H-indene(1- $\left.\alpha, 2-\beta, 3 \mathrm{a}-\alpha, 4-\beta, 7-\beta, 7 \mathrm{a}-\alpha\right)$

$111,2,3,4,5,6,7,8,8$-Nonachloro-2,3,3a,4,7,7a-hexahydro-4,7-methano-1H-indene $(1-\alpha, 2-\alpha, 3-\alpha, 3 \mathrm{a}-\alpha, 4-\beta, 7-\beta, 7 \mathrm{a}-\alpha)$

$121,2,3,4,5,6,7,8,8$-Nonachloro-2,3,3a,4,7,7a-hexahydro-4,7-methano- $1 \mathrm{H}$-indene $(1-\alpha, 2-\beta, 3-\alpha, 3 \mathrm{a}-\alpha, 4-\beta, 7-\beta, 7 \mathrm{a}-\alpha)$

$132,3,4,5,6,6 \mathrm{a}, 7,7$-Octachloro-1a,1b,5,5a,6,6a-hexahydro-2,5-methano- 2 H-indeno(1,2-b)oxirene(1a- $\alpha, 1 \mathrm{~b}-\beta, 2-\alpha, 5-\alpha, 5 \mathrm{a}-\beta, 6-\beta, 6 \mathrm{a}-\alpha)$

${ }^{14} 1,4,5,6,7,8,8$-Heptachloro-2,3,-epoxy-3a,4,7,7a-tetrahydro-4,7-methano-1H-indene

${ }_{15}$ Sum of cis- and trans-chlordanes and nonachlors; oxychlordane; and heptachlor epoxide

${ }_{16}$ 1,1a,2,2,3,3a,4,5,5,5a,5b,6-Dodecachloro-octahydro-1,3,4-metheno-1H-cyclobuta(cd)pentalene

${ }^{17}$ Perchlorobenzene

${ }^{18}$ Sum of $\alpha$ - and $\gamma$-hexachlorocyclohexane

streams. Analysis using Levene's test indicated that the log-transformed $p, p^{\prime}$-DDE concentrations reasonably approximated normality. Transformed concentrations in carp and bass were therefore tested by analysis of variance (ANOVA) using a nested linear model that included terms for subbasin, program, and sex. This analysis revealed small but nevertheless significant $(\mathrm{p}<0.05)$ differences between genders for $p, p^{\prime}$-DDE in carp but not in bass (data not shown). Consequently, four stations $(23,29,76$, and 77$)$ were eliminated from the geographic statistical analysis of $p, p^{\prime}$-DDE in carp due to either mixed-gender compositing (caused by fish that either could not be identified to sex or were misidentified in the field, as verified by histopathological examination of preserved gonad samples) or the collection of only one gender at the station. Differences among means were compared using Fisher's protected LSD. Temporal changes for $p, p^{\prime}$-DDE at individual NCBP stations were tested by analyzing the log-transformed concentrations in the 141 station-year-species combinations (total $n=242$ ) in the combined-year data set as a one-way ANOVA. Fisher's protected LSD was then used to contrast only the 36 pairs of station-year-species means representing 1995 vs. 1986 concentrations (1984 for Station 90) in the same species at a site. For other compounds the unweighted species (or higher-order taxon) and station-species means at NCBP sites were compared graphically with findings from the most recent NCBP collection (1984 or 1986; data not shown). 


\section{Results and Discussion}

\section{DDT and Its Primary Metabolites}

Prior to 1972 the insecticide DDT (dichlorodiphenyltrichloroethane) was used to control many pests throughout the United States Environmental residues of DDT and its degradation products therefore persist in many areas from historic use, especially in cotton-growing regions (Schmitt et al. 1999c). Residues also remain evident near sites of former DDT production and synthesis and as a result of atmospheric transport from parts of the world where DDT is still used. Although long-lived, $p, p^{\prime}$-DDT, the active insecticide, is metabolized by vertebrates to a number of other residues, the most stable and toxic of which is $p, p^{\prime}$-DDE. In 1995 (note: here and elsewhere, 1996 for Station 400), DDT residues (as $p, p^{\prime}$-DDE) were detected in $91 \%$ of the samples and at all stations (Figure 2 and 3 , Table 2), including the reference site (Figure 2). Total DDT concentrations (sum of $p, p^{\prime}$-homologs) in individual 1995 samples ranged from nondetectable $(<0.01 \mu \mathrm{g} / \mathrm{g})$ to $11 \mu \mathrm{g} / \mathrm{g}$ (Table 2). All of the greatest concentrations of total DDT (i.e., $\geq 1.0 \mu \mathrm{g} / \mathrm{g}$ ) and of $p, p^{\prime}$-DDE occurred in the southernmost part of the MRB, at NAWQA Stations 201, 202, 203, and 204 (in the MSE Study Unit) and at NCBP Station 80 (Yazoo R. at Redwood, MS; Figure 2 and 3). These concentrations were about 10-fold greater than those reported by Tate and Heiny (1996) in fish from the South Platte River basin. Total DDT concentrations in fish from Station 400 were $0.3-0.4 \mu \mathrm{g} / \mathrm{g}$ (mostly as $p, p^{\prime}$-DDE) in carp and $<0.1 \mu \mathrm{g} / \mathrm{g}$ in largemouth bass (Figure 2).

The predominant homolog in all 1995 samples with detectable residues was $p, p^{\prime}$-DDE (Figure 3). Next most abundant was $p, p^{\prime}$-DDD, an anaerobic metabolite of $p, p^{\prime}$-DDT that was also used historically as an insecticide. Traces $(<0.02 \mu \mathrm{g} / \mathrm{g})$ of $p, p^{\prime}$-DDT, the parent insecticide, were found in only seven samples-two from each of Stations 80, 24 (Ohio R. at Marietta, $\mathrm{OH}$ ), and 28 (Arkansas R. at Pine Bluff, AR) and one from Station 67 (Allegheny R. at Natrona, PA). Station 80 has a long history of contamination by DDT and other organochlorine pesticides from cotton farming in the Yazoo River basin, and Station 28 is influenced by a facility at which DDT was synthesized for military use. No $p, p^{\prime}$-DDT was detected in any sample from the NAWQA sites, including those in the Yazoo basin, despite fivefold greater total DDT concentrations in all samples from Stations 201-204 than at Station 80 (Figure 2). Traces of $o, p^{\prime}$-DDT homologs, mostly as the degradation product $o, p^{\prime}$-DDD, were present in at least one sample from the reference site (Station 400); at NCBP Stations 28 (Arkansas R.), 67 (Allegheny R.), 68 (Wabash R. at New Harmony, IN), 80, and 81; and NAWQA Stations 201-204 (all in the MSE Study Unit) and 211 (Cedar R. at St. Charles City, IA; data not shown $)$. Most concentrations were low $(<0.05 \mu \mathrm{g} / \mathrm{g} ; \leq 10 \%$ of $p, p^{\prime}$-DDE) and occurred in samples that also contained at least slightly elevated concentrations of $p, p^{\prime}$-DDE. A notable exception was Station 24 (Ohio R. at Marietta, OH), where $o, p^{\prime}$-homologs occurred at about the same concentration as $p, p^{\prime}$-homologs (approximately $0.5-0.6 \mu \mathrm{g} / \mathrm{g}$ ) in both carp and bass and where samples also contained traces of $p, p^{\prime}$-DDT (Table 2). Such high relative concentrations of $o, p^{\prime}$ homologs together with traces of $p, p^{\prime}$-DDT suggest recently mobilized DDT at this site (Aguillar 1984; Nowell et al. 1999).

Among NCBP sites sampled in 1995, total DDT concentrations were greatest at Stations 80 and 81, as they were in 1986 (Schmitt et al. 1999c). The mean 1995 total DDT concentration at Station 80 was $1.2 \mu \mathrm{g} / \mathrm{g}$, mostly as $p, p^{\prime}$-DDE (Figure 3 ). In 1986, the Station 80 mean was $2.5 \mu \mathrm{g} / \mathrm{g}$ and included about 0.3 $\mu \mathrm{g} / \mathrm{g}(12 \%)$ of $p, p^{\prime}$-DDT (Schmitt et al. 1999c). Total DDT concentrations also declined, but to a lesser extent, at NCBP Station 81 (Red R. at Alexandria, LA), from a mean of $0.5 \mu \mathrm{g} / \mathrm{g}$ in 1986 to about $0.3 \mu \mathrm{g} / \mathrm{g}$ in 1995 . However, it should be noted that there were no taxa in common to both the 1986 and 1995 collections at either of these stations. Nationally, Station 80 historically yielded fish with the greatest concentrations of total DDT; concentrations were $10-30 \mu \mathrm{g} / \mathrm{g}$ in the early $1970 \mathrm{~s}$ (Schmitt et al. 1981) and declined steadily to 2-6 $\mu \mathrm{g} / \mathrm{g}$ in 1986 (Schmitt et al. 1999c) and $<3 \mu \mathrm{g} / \mathrm{g}$ in 1995. Total DDT concentrations in fish collected in 1995 from NAWQA Stations 201-204 (4-11 $\mu \mathrm{g} / \mathrm{g}$ ) were comparable to Station 80 concentrations of the late 1970s and early 1980s (Schmitt et al. 1983, 1985). Concentrations also declined at most of the stations where within-taxon comparisons could be made. The exceptions were carp and largemouth bass from Station 67 (Allegheny R.) and carp from Station 82 (L. Texoma), in which concentrations increased slightly; however, these increases were only marginally statistically significant (Fisher's protected LSD; $p=0.08$ for Station 67 carp, $p=0.15$ for Station 67 bass, and $\mathrm{p}=0.07$ for Station 82 carp). In contrast, $p, p^{\prime}$-DDE declined significantly $(\mathrm{p}<0.05)$ in carp from Stations 25 (Tennessee R.), 29 (Arkansas R.), 70 (Ohio R. at Metropolis, OH), 76 (Mississippi R. at Memphis, TN), 78 (Verdigris R.), 79 (Canadian R.), 85 (Yellowstone R.), 86 (James R.), and 112 (Mississippi R. at Dubuque, IA). No differences in other species were statistically significant $(\mathrm{p}>$ $0.01)$.

Residues of DDT (as $p, p^{\prime}$-DDE) were detected in about $95 \%$ of the carp and bass samples analyzed (Table 2). Concentrations differed significantly $(\mathrm{p}<0.01)$ among subbasins and between NAWQA and NCBP stations (Table 3). Most subbasins differed significantly $(\mathrm{p}<0.01)$ from each other and from the reference site for both carp and bass, but most mean concentrations were low and the differences were small (Table $3)$. The exception was the MSE Study Unit, where concentrations of $p, p^{\prime}$-DDE in carp were significantly $(\mathrm{p}<0.01)$ greater than in all MRB subbasins, including the Lower Mississippi River (in which the MSE Study Unit is contained). In contrast, $p, p^{\prime}$-DDE concentrations in EIB carp were significantly $(\mathrm{p}<$ 0.01) lower than in carp from the Upper Mississippi River subbasin; however, the concentrations were low in both and the differences were small (Table 3). As a group, $p, p^{\prime}$-DDE concentrations were significantly greater $(p<0.01)$ in carp from the NAWQA sites than from the NCBP sites due to the very high levels in fish from the MSE Study Unit, but only the mean for NCBP sites differed significantly from the reference site where concentrations in carp were very low (Table 3 ). Concentrations in bass did not differ significantly between NCBP and NAWQA sites (two stations); however, concentrations at the NCBP stations, but not the NAWQA sites, were significantly lower than at the reference site (Table 3).

The proportional composition of the DDT mixture present in U.S. freshwater fish gradually changed after the 1972 U.S. ban. 




\section{Sub-basin and Station}

Fig. 2. Concentrations of $p, p^{\prime}$-DDE in composite samples of whole fish, by station, subbasin, and taxon. Censored values are plotted as $0.005 \mu \mathrm{g} / \mathrm{g}$ (50\% LOD). See Table 1 for station locations and subbasins

From 1970 to $1980-81, p, p^{\prime}$-DDE accounted for about $70 \%$ of total DDT (Schmitt et al. 1981, 1983, 1985), then increased to $73 \%$ in 1984 (Schmitt et al. 1990) and 74\% in 1986 (Schmitt et al. 1999c), reflecting the reduced influx and continuing weathering of $p, p^{\prime}$-DDT in the environment. In 1995, the average for MRB stations with detectable DDT residues was still about $75 \%$. Residues of $p, p^{\prime}$-DDE, were detected at all or nearly all NCBP stations in every collection from 1970 through 1986 (Schmitt et al. 1985, 1990, 1999c).

In terms of ecological risk, the U.S. Environmental Protection Agency (EPA) ambient water quality criterion for DDT (US EPA 1980) is based on a value of $0.15 \mu \mathrm{g} / \mathrm{g}$ (total DDT) in fish for the protection of reproduction in the brown pelican (Pelicanus occidentalis), the most sensitive species evaluated (Anderson et al. 1975); for other avian species, the range is 1-3 $\mu \mathrm{g} / \mathrm{g}$ (Blus 1996). However, the Canadian wildlife value for total DDT is $0.14 \mu \mathrm{g} / \mathrm{g}$ (Environment Canada 1999) and the New York guideline is $0.2 \mu \mathrm{g} / \mathrm{g}$ (Newell et al. 1987). Relative to higher values of Blus (1996), the 1995 DDT residues in fish from NCBP and NAWQA sites in the lower MRB represent a hazard to most fish-eating birds (Figure 2). Using the lower values (US EPA 1980; Newell et al. 1987; Environment Canada 1999), sensitive species may also be at risk in the ARR and OHR subbasins and at the reference site. In laboratory-exposed freshwater fish, toxic effects have been observed at whole-body total DDT concentrations $\geq 0.5 \mu \mathrm{g} / \mathrm{g}$ in some studies (Jarvinen and Ankley 1999), but there is great variation among species and exposure regimes.

\section{Toxaphene}

Following the 1972 U.S. ban on DDT use, toxaphene became the insecticide most heavily used on cotton until it also was banned in the early 1980s (US EPA 1982). The geographic distribution of toxaphene residues among the 1995 samples reflects this historic use pattern. Toxaphene was detected in only 12 samples, all from five sites in the lower MRB-NCBP Station 80 (Yazoo R.) and NAWQA Stations 201-204, the latter all in the MSE Study Unit (data not shown). These represent only $7 \%$ of the samples and $11 \%$ of the stations (Table 2) and are the same sites at which total DDT concentrations were greatest (Figure 2). In 1986, toxaphene was detected at $64 \%$ of the NCBP stations at a twofold greater LOD $(0.1 \mu \mathrm{g} / \mathrm{g})$. The 1995 toxaphene concentrations at NCBP Station 80 were $0.8-2.5 \mu \mathrm{g} / \mathrm{g}$ in carp and $0.5-0.7 \mu \mathrm{g} / \mathrm{g}$ in largemouth bass (mean about $1 \mu \mathrm{g} / \mathrm{g}$ ) but were generally higher (means $2.0-4.0 \mu \mathrm{g} / \mathrm{g}$, maxima $2.0->8.0 \mu \mathrm{g} / \mathrm{g}$ ) in carp from Stations 201-204 (data not shown). Although elevated relative to other 1995 sites, levels at Station 80 declined substantially over the past two decades; concentrations were $0.4-2.4 \mu \mathrm{g} / \mathrm{g}$ in 1986 (Schmitt et al. 1999c) and 10-20 $\mu \mathrm{g} / \mathrm{g}$ in the late 1970s 


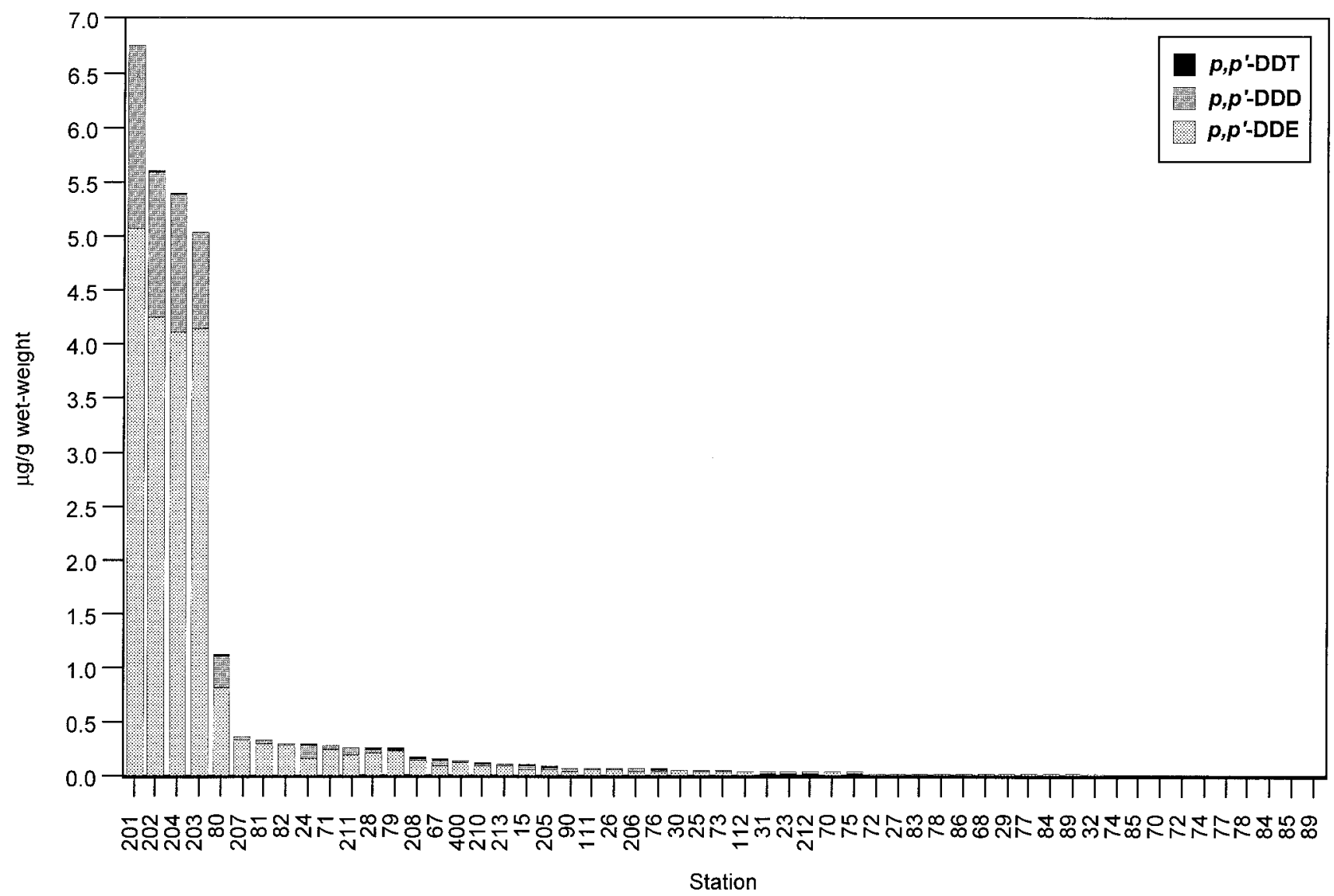

Fig. 3. Ranked geometric mean concentrations of $p, p^{\prime}$-DDT homologs in composite samples of whole fish, by station. (Note: Censored values were represented by $50 \%$ of LOD in the totals and means but are not shown.) See Table 1 for station locations

and early 1980s (Schmitt et al. 1981,1983, 1985). Similar to the pattern observed for DDT, toxaphene concentrations in fish from NAWQA Stations 201-204 remained about at the levels observed at Station 80 in the early 1980s (Schmitt et al. 1983, 1985). In contrast to DDT, which declined by about $50 \%$ from 1986 to 1995 , the geometric mean concentration of toxaphene at Station 80 was about the same in 1995 as in 1986; however, there were no taxa common to both collections at Station 80, so this comparison should be considered with caution. At NCBP stations with species common to both collections the trends were uniformly downward, however (data not shown).

Toxaphene is a complex mixture of chlorinated camphenes that is difficult to analyze by GC-ECD because of interferences from coeluting PCB congeners and other ubiquitous environmental residues. Consequently, negative chemical ionization (NCI) GC/MS is the preferred analytical method (Ribick et al. 1982; Muir and de Boer 1993). Nevertheless, reasonably good concentration estimates can be achieved by capillary-column GC-ECD if toxaphene is fractionated away from PCBs (e.g., Krock et al. 1997), as was done with the 1995 samples; and concentrations of PCBs and chlordane are low relative to those of toxaphene, as was true in the 12 toxaphene-containing samples from stations in the MSE Study Unit and Station 80 (see following discussion). Nevertheless, the toxaphene concentrations reported here and in the past should be considered estimates.
Toxaphene is highly toxic to fish (Johnson and Finley 1980); adverse effects on freshwater fish have been associated with whole-body residues $\geq 1.0 \mu \mathrm{g} / \mathrm{g}$ in laboratory studies with technical toxaphene (Jarvinen and Ankley 1999), a level exceeded by some 1995 samples. However, all the samples from Station 80 and the MSE NAWQA sites exceeded $0.0063 \mu \mathrm{g} / \mathrm{g}$, the Canadian wildlife guideline (Environment Canada 1999). Regardless, the composition and potential toxicity of differentially weathered toxaphene can vary greatly (Harder et al. 1983; Gooch and Matsumura 1987; Bidleman et al. 1993).

\section{Cyclodiene Insecticides}

The insecticides dieldrin; aldrin $(1,2,3,4,10,10$-hexachloro1,4,4a,5,8,8a-hexahydro-1,4-endo-exo-5,8-dimethanonaphthalene), which is metabolized to dieldrin; chlordane (mixture of related compounds); and heptachlor (1,4,5,6,7,8,8-heptachloroepoxy-3a,4,7,7a-tetrahydro-4,7-methano-1H-indene), which is metabolized to heptachlor epoxide, were used against a variety of soil-dwelling insects, including corn rootworms (Diabrotica spp.) and termites. These compounds bind tightly to soil particles and persist in many areas from historic uses (Schnoor 1981; Rostad 1997; Nowell et al. 1999). Endrin was used extensively on cotton and, to a lesser extent, against army 
Table 3. Geometric mean concentrations of $p, p^{\prime}$-DDE in composite samples of whole carp and bass, by subbasin and program (as defined in Table 1) and for the reference site in West Virginia (also shown are ANOVA $\mathrm{F}$ values, $* * \mathrm{p}<0.01$ )

\begin{tabular}{lll}
\hline & \multicolumn{2}{l}{ Taxon } \\
\cline { 2 - 3 } Subbasin or Program & $\operatorname{Carp}\left(\mathrm{F}=35.05^{* *}\right)$ & Bass $\left(\mathrm{F}=18.82^{* *}\right)$ \\
\hline Subbasins & & \\
Arkansas-Red R. & $0.11^{1} \mathrm{ac}$ & $0.04_{\mathrm{a}}$ \\
Lower Missouri R. & $0.02_{\mathrm{b}}$ & $0.01_{\mathrm{b}}$ \\
Upper Missouri R. & $0.01_{\mathrm{b}}$ & $0.01_{\mathrm{b}}$ \\
Lower Mississippi R. & $0.15^{2} \mathrm{a}$ & $0.12_{\mathrm{c}}$ \\
Upper Mississippi R. & $0.04_{\mathrm{c}}$ & $0.02_{\mathrm{bd}}$ \\
Ohio R. & $0.07^{3} \mathrm{ac}$ & $0.04_{\mathrm{ad}}$ \\
Eastern Iowa Basins & $0.09_{\mathrm{c}}$ & $-5^{\mathrm{a}}$ \\
Mississippi & & \\
Embayment & $1.00_{\mathrm{d}}$ & $0.04_{\mathrm{ad}}$ \\
Reference & $0.27_{\mathrm{a}}$ & $0.06_{\mathrm{ac}}$ \\
Programs & & \\
NCBP stations & $0.05^{5}{ }_{\mathrm{a}}$ & $0.03_{\mathrm{a}}$ \\
NAWQA stations & $0.29_{\mathrm{b}}$ & $0.04_{\mathrm{ab}}$ \\
Reference & $0.27_{\mathrm{b}}$ & $0.06_{\mathrm{b}}$ \\
\hline
\end{tabular}

See text for statistical methods. Within each of the four groups, (taxa, subbasins, programs), means containing the same subscript are not significantly different (ANOVA, $\mathrm{p}>0.05$ ).

${ }^{1}$ Does not include Stations 29 or 77.

${ }^{2}$ Does not include Station 76.

${ }^{3}$ Does not include Station 23.

${ }^{4}$ Only carp were collected in the EIB study unit.

${ }^{5}$ Does not include Stations 23, 29, 76, or 77 .

cutworms (Euoxoa axilliaris) infesting wheat in the Great Plains and to protect orchards from rodents (Schmitt et al. 1990). Endosulfan $(6,7,8,9,10,10$-hexachloro-1,5,5a,6,9,9ahexahydro-6,9-methano-2,4,3-benzodioxathiepin-3-oxide) is the only cyclodiene pesticide currently used in North America, but others are synthesized domestically for export.

Dieldrin: Greatest concentrations of dieldrin were historically found in fish from the Midwest (see Schmitt et al. [1999c] and references therein). In the MRB, this pattern persisted into 1995; dieldrin residues were present in $42 \%$ of the samples from $57 \%$ of the stations, at concentrations ranging from barely detectable (about $0.01 \mu \mathrm{g} / \mathrm{g}$ ) to $0.25 \mu \mathrm{g} / \mathrm{g}$ (Figure 4, Table 2). Greatest 1995 concentrations occurred in the central and southern parts of the basin, as they have historically. Geometric station means were $>0.025 \mu \mathrm{g} / \mathrm{g}$ at NCBP Stations 76 (Mississippi R. at Memphis, TN), 26 (Illinois R. at Hardin, IL), 68 (Wabash R. at New Harmony, IN), 73 (Des Moines R. at Keosauqua, IA), 75 (Mississippi R. at Cape Girardeau, MO), 31 (White R. at Devall's Bluff, AR), 83 (Missouri R. at Hermann, MO), 80 (Yazoo R.), and 90 (Kansas R. at Bonner Springs, KS) and at NAWQA Stations 205, 206 and 210, in the EIB Study Unit (data not shown). The greatest individual sample concentrations $(0.10-0.25 \mu \mathrm{g} / \mathrm{g})$ were from Stations 76, 206, 83, 68, and 67 (Allegheny R. at Natrona, PA; Figure 4 , Table 2). Concentrations at most sites in the central MRB compare favorably to 1992-93 values reported for the South Platte River system by Tate and Heiny (1996) and confirm the presence of relatively high values in fish from agricultural and urban watersheds in Iowa (Roberts 1997); however, the 1995 MRB maxima were at least twice those reported by either of the latter studies. No dieldrin residues were detected in samples from the reference site (Figure 4).

From the mid-1980s to 1995 , dieldrin concentrations declined by $50 \%$ or more at most of the NCBP stations in the MRB with the greatest historic concentrations (c.f. Schmitt et al. 1990, 1999c). This finding supports other research showing that significant amounts of this and other soil-associated compounds were transported out of the MRB by the floods of 1993 and 1995 (Rostad 1997). Dieldrin concentrations were also relatively high in the past at NCBP Station 90 (Kansas R.), which was not sampled in 1986; however, compared to 1984, concentrations there also declined but not to the extent that it did at other stations. Station 76 was an exception in that concentrations were twice as high in 1995 than in 1986. Some of this increase may reflect taxonomic differences; freshwater drum (Aplodinotus grunniens) and bluegill were collected in 1986, whereas carp and largemouth bass were collected in 1995. Carp were collected in 1984, however, when concentrations were $0.08-0.11 \mu \mathrm{g} / \mathrm{g}$ (Schmitt et al. 1990)—about $50 \%$ lower than in 1995 (Figure 4). Although some of the elevated cyclodiene pesticide levels in fish from Station 76 can no doubt be attributed to agricultural pesticide use in the Midwest and termite control efforts in Memphis and elsewhere in the MRB (Nowell et al. 1999), high concentration of dieldrin, endrin, and other cyclodiene insecticides at this site have long been attributed to a manufacturing source near Memphis (Schmitt et al. 1981, 1983, 1985, 1990, 1999c) and from a landfill containing pesticide manufacturing wastes (Leppanen et al. 1998). In the past, chemical spills at the manufacturing site caused massive fish kills (Biglane et al. 1964), and fish from the Mississippi River contained residues of cyclodiene insecticide precursors (Yurawecz and Roach 1978). Among other NCBP stations with taxa in common to the 1986 and 1995 collections, dieldrin concentrations declined or changed only slightly at most (data not shown). The exception was Stations 67 (Allegheny R.), where concentrations in carp also increased.

Adverse effects have been observed in laboratory studies with freshwater fish at whole-body dieldrin concentrations $\geq 1.2-1.4 \mu \mathrm{g} / \mathrm{g}$ (Jarvinen and Ankley 1999), which is about fivefold greater than the highest 1995 concentration (about 0.25 $\mu \mathrm{g} / \mathrm{g}$ at Station 76; Figure 4). This concentration is also more than 10-fold lower than dietary concentrations associated with adverse effects in wildlife (see review by Peakall [1996]). However, it is only twice the NYSDEC wildlife guideline of $0.12 \mu \mathrm{g} / \mathrm{g}$ (Newell et al. 1987). Based on this lower value, dieldrin residues in fish from Station 206 may also represent a hazard to piscivorous wildlife (Figure 4). Evidence cited by Schmitt et al. (1985, 1990) suggested that dieldrin was still being carried into receiving waters from fields in the Midwest, despite the fact that no aldrin (the source of most environmental dieldrin residues) had been used in agriculture since 1974 (Schnoor 1981). The more recent data of Rostad (1997) and the $50 \%$ lower concentrations present in fish in 1995 relative to 1986 indicate that these compounds are still present, but concentrations are generally low and declining.

Endrin: Low concentrations of endrin (about $0.2 \mu \mathrm{g} / \mathrm{g}$ ) were historically present in fish from NCBP sites in the South and Midwest (Schmitt et al. 1981, 1983, 1985, 1990, 1999c). Al- 


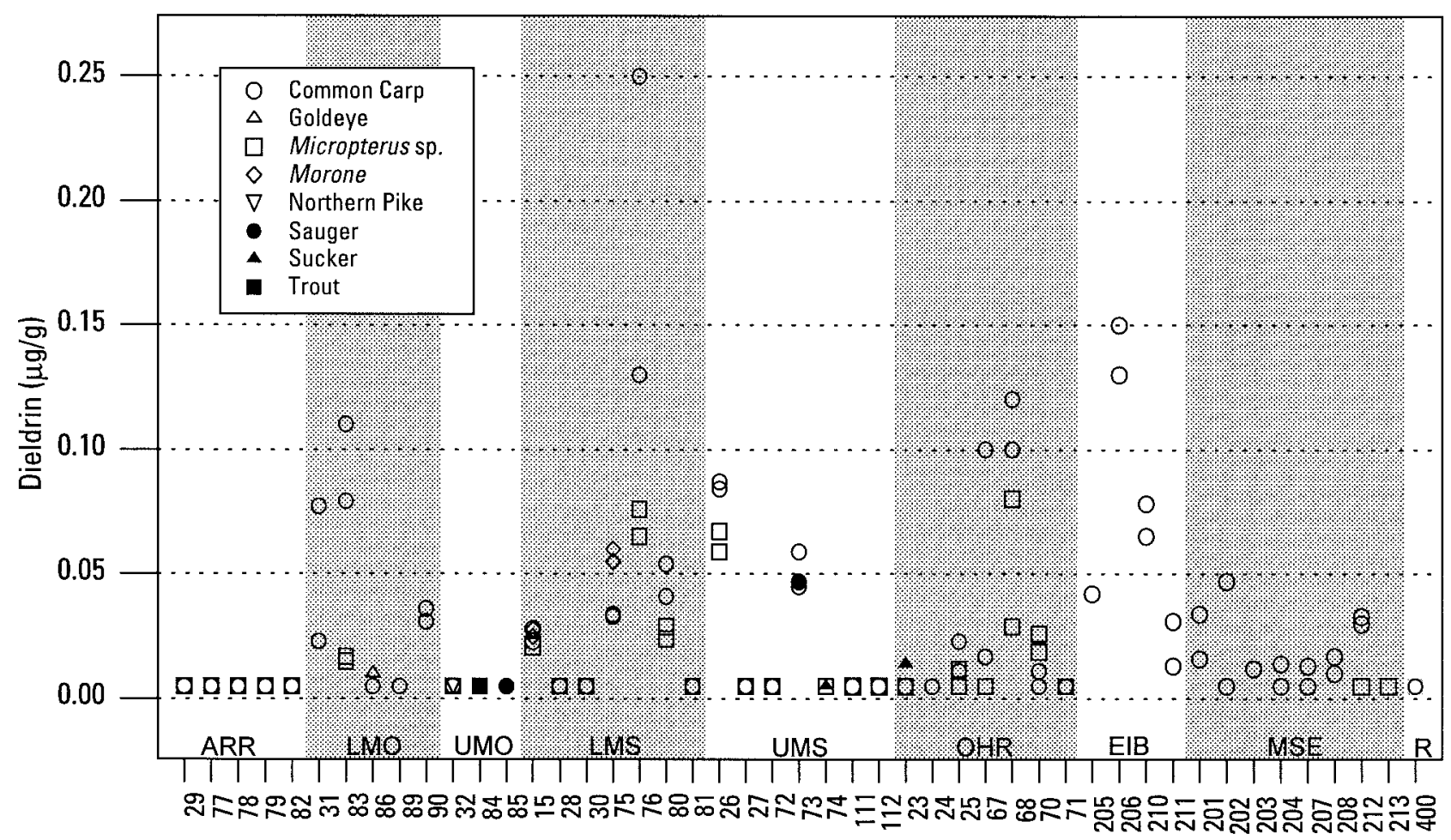

Sub-basin and Station

Fig. 4. Concentrations of dieldrin in composite samples of whole fish, by station, subbasin, and taxon. Censored values are plotted as $0.005 \mu \mathrm{g} / \mathrm{g}$ (50\% LOD). See Table 1 for station locations and subbasins

though banned for most uses in 1984, it was used sporadically in the northern Great Plains through the 1980s, and Tate and Heiny (1996) detected $0.1-0.2 \mu \mathrm{g} / \mathrm{g}$ of endrin in fish collected from the Platte River system in 1992-93. In 1995, endrin was present in only four samples (Table 2), all from NCBP Station 76 (Mississippi R. at Memphis). This site historically produced the highest endrin concentrations among NCBP stations (Schmitt et al. 1999c) owing to the point sources described previously. The 1995 concentrations at Station 76 were 0.22 $\mu \mathrm{g} / \mathrm{g}$ in largemouth bass (both samples) and $0.40-0.71 \mu \mathrm{g} / \mathrm{g}$ in carp (geometric station mean $0.34 \mu \mathrm{g} / \mathrm{g}$; data not shown), which is about fivefold greater than the 1986 mean for bluegill and freshwater drum from that site. In 1984, the concentrations in carp were 0.01-0.22 $\mu \mathrm{g} / \mathrm{g}$ (Schmitt et al. 1990).

Endrin is among the most toxic organochlorine insecticides to fish (Grant 1976; Johnson and Finley 1980). In laboratory studies with freshwater fish, adverse effects have been observed at whole-body concentrations as low as $0.01 \mu \mathrm{g} / \mathrm{g}$ (Jarvinen and Ankley 1999), the nominal 1995 detection limit exceeded only by the samples from Station 76. In contrast to the safety margin observed for dieldrin, the 1995 endrin concentrations $(0.2-0.7 \mu \mathrm{g} / \mathrm{g})$ in Station 76 carp from were only about two- to fourfold lower than the lowest dietary concentrations known to be toxic to avian wildlife (see review by Peakall [1996]). Station 76 concentrations were 10-fold greater than the New York wildlife guideline (Newell et al. 1987), however.
Chlordane and Heptachlor: Residues of chlordane components, heptachlor (as heptachlor epoxide), and their metabolites were among the most widely distributed organochlorine compounds detected in the 1995 samples. Residues of at least one of the measured chlordane-related compounds (cis-chordane, trans-chlordane, cis-nonachlor, trans-nonachlor, oxychlordane, and heptachlor epoxide) were present in $51 \%$ of the samples from $70 \%$ of the stations sampled (Table 2). None were detected in any of the samples from Station 400 (reference site). The geographic distribution of these compounds closely resembled that of dieldrin. The greatest mean total concentrations $(0.07-0.25 \mu \mathrm{g} / \mathrm{g})$ of chlordane-related compounds occurred in the central and southern parts of the MRB-at NCBP Stations 76 (Mississippi R. at Memphis), 68 (Wabash R. at New Harmony, IN), 23 (Kanawha R. at Nitro, WV), 24 (Ohio R. at Marietta, OH), 67 (Allegheny R. at Natrona, PA), 73 (Des Moines R. at Keosauqa, IA), 90 (Kansas R. at Bonner Springs, KS), and 26 (Illinois R. at Hardin, IL) and at NAWQA Stations 206 (Iowa R. at Morengo R., IA), 205 (S. Skunk R. at Oskaloosa, IA), and 201 (Big Sunflower R. at Anguilla, MS; Figure 5 and 6). The individual samples containing the highest concentrations $(0.25-0.55 \mu \mathrm{g} / \mathrm{g}$ of total chlordane-related compounds) were the two carp samples from Station 76, one carp sample from Station 206, and one each of bass and smallmouth buffalo from Station 23 (Figure 5, Table 2). These concentrations are about fivefold greater than the maximum 1992-93 concentrations reported for urban and mixed land-use sites in the Platte River system by Tate and Heiny (1996), but they 


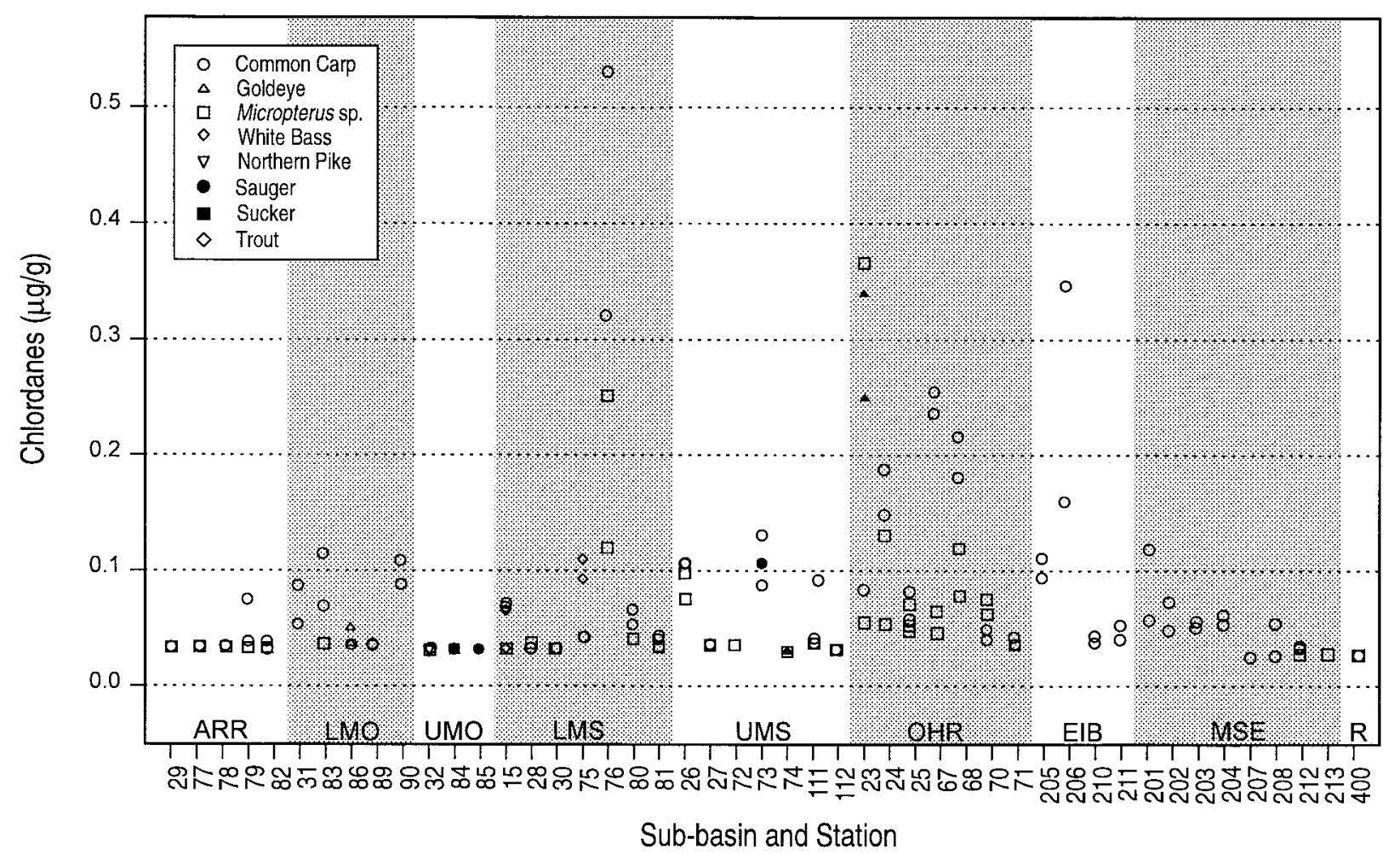

Fig. 5. Concentrations of total chlordane-related residues (sum of cis- and trans-chlordanes and nonachlors; oxychlordane; and heptachlor epoxide) in composite samples of whole fish, by station, subbasin, and taxon. Censored values were represented as $0.005 \mu \mathrm{g} / \mathrm{g}(50 \% \mathrm{LOD})$ for each compound. See Table 1 for station locations and subbasins

compare favorably with those reported for agricultural areas of Iowa by Roberts (1997). In 1984, the most recent NCBP collection in which carp were collected from Station 23, concentrations at that site were about the same as in 1995-0.21$0.59 \mu \mathrm{g} / \mathrm{g}$ (Schmitt et al. 1999c).

Heptachlor, aldrin, dieldrin, and chlordane were all used against ants, termites, corn rootworms, and other soil-dwelling insects, and residues of the individual compounds and their metabolites therefore tend to co-occur (Schmitt et al. 1990). Heptachlor also occurs as a minor component $(\leq 10 \%)$ of technical chlordane (NRCC 1974), and small amounts of cisand trans-chlordane are present in technical heptachlor (Eisler 1990; Wiemeyer 1996). It is therefore difficult to differentiate the source(s) of environmental heptachlor- and chlordane-derived residues (Schmitt et al. 1985). Heptachlor is rapidly converted to heptachlor epoxide and other metabolites by many organisms, and the use of this compound was phased out by the early 1980s (Wiemeyer 1996). Consequently, little or no unmetabolized heptachlor was detected in NCBP fish samples after 1976-77. Both the occurrence and the concentrations of heptachlor epoxide were declining through the mid-1980s; in 1986 , concentrations were $\geq 0.04 \mu \mathrm{g} / \mathrm{g}$ in one or more samples from only NCBP Stations 75 (Mississippi R. at Cape Girardeau, MO), 26 (Illinois R. at Hardin, IL), and 83 (Missouri R. at Hermann, MO) (Schmitt et al. 1999c). In 1995, residues of heptachlor epoxide were present in only 14 samples (9\%) from seven stations $(15 \%)$, mostly as trace concentrations $(<$ $0.02 \mu \mathrm{g} / \mathrm{g})$. Greater-than-trace concentrations $(0.03-0.05$ $\mu \mathrm{g} / \mathrm{g}$ ) were present only in carp from NAWQA Station 206 (Iowa R. at Morengo, IA; Table 2, Figure 6).

The 1995 concentrations of chlordane-related compounds were lower at most NCBP sites than they were in 1986 (Schmitt et al. 1999c). Nationally, chlordane concentrations declined steadily from 1976 to 1981 (Schmitt et al. 1983, 1985), but then changed little from 1980-81 to 1986 (Schmitt et al. 1990, 1999c). As described for other cyclodiene insecticides, Station 76 was an exception; concentrations were higher in 1995 than in 1986, with the same caveat that different taxa were collected in 1995. Chlordane concentrations generally declined or changed little at stations with taxa in common to both collections (data not shown).

The incidence of the most abundant and persistent chlordane constituents has been declining since the early 1980s. In 1980 81 , cis-chlordane was detected at $74 \%$ of the NCBP stations sampled and trans-nonachlor at $85 \%$, having declined from 93\% in 1978-79 (Schmitt et al. 1983, 1985). By 1984-86, residues of cis-chlordane and trans-nonachlor were present at only $70 \%$ and $74 \%$, respectively, of the NCBP stations sampled (Schmitt et al. 1990, 1999c). In 1995, trans-nonachlor was again the most frequently detected chlordane constituent; it was present $51 \%$ of the samples from $70 \%$ of the stations (Table 2). Residues of cis-chlordane were next in concentration and abundance ( $21 \%$ of the samples from $48 \%$ of the stations; Table 2 ). At Stations 76, however, trans-chlordane was the most abundant component in 1995 (Figure 6), which may reflect the influence of the point sources noted for dieldrin and endrin. In 




Fig. 6. Ranked geometric mean concentrations of chlordane-related compounds in composite samples of whole fish, by station. (Note: Censored values were represented by $50 \%$ of LOD in the totals and means but are not shown.) See Table 1 for station locations

1986, the maximum chlordane concentration $(0.78 \mu \mathrm{g} / \mathrm{g})$ occurred at NCBP Station 69 (Ohio R. at Cincinnati, OH), which was not sampled in 1995, and relatively high concentrations of one or more chlordane-related compounds (cis- or trans-chlordane or nonachlor; oxychlordane; heptachlor epoxide) were also present in fish from Stations 70 (Ohio R. at Metropolis, IL), 83 (Missouri R. at Hermann, MO), and 67 (Allegheny R.).

Oxychlordane, a highly toxic metabolite of cis-chlordane, and heptachlor epoxide were also present at most of these sites in 1986 but at lower concentrations than the other chlordane components. As noted for dieldrin, chlordane concentrations were also relatively high in the past at NCBP Station 90 (Kansas R.), which was not sampled in 1986. In 1995 chlordane concentrations at Station 90 were about the same as they were in 1984 (geometric mean $0.03 \mu \mathrm{g} / \mathrm{g}$ ). In general, the compositional change in the chlordane mixture present in fish collected in 1995 compared to 1986 reflects the continued weathering of these compounds, and the decline in concentrations at most NCBP sites from 1986 to 1995 further supports the hypothesis that large quantities of cyclodiene insecticides were transported out of the MRB by the floods of 1993 and 1995 (Rostad 1997).

In terms of ecological risk, a total concentration of $0.3 \mu \mathrm{g} / \mathrm{g}$ for cis-chlordane, trans-chlordane, and oxychlordane in whole fish was proposed as a temporary guideline for vertebrate wildlife protection (Eisler 1990). This level was exceeded by some of the most heavily contaminated 1995 samples (Table 2, Figure 5), but not by any geometric station means (Figure 6). Only one sample from Station 76 exceeded $0.5 \mu \mathrm{g} / \mathrm{g}$, the New York wildlife guideline for chlordanes (Newell et al. 1987). In laboratory exposures of freshwater fish, the lowest heptachlor and heptachlor epoxide residue concentrations associated with adverse effects are several orders of magnitude greater than levels present in the 1995 samples (Jarvinen and Ankley 1999), but there are no data for chlordane. Paddlefish (Polyodon spathula) eggs from the Ohio River collected in 1997 contained $0.35 \mu \mathrm{g} / \mathrm{g}$ of chlordane and $0.74 \mu \mathrm{g} / \mathrm{g}$ of PCBs (Gundersen et al. 2000), similar to levels observed in the 1995 samples from the OHR subbasin (Figure 6). The testes of male Ohio River paddlefish contained fourfold greater concentrations and possible contaminant-related effects on the adult fish, but not on hatching success, were noted (Gundersen et al. 2000).

\section{Hexachlorocyclohexane $(\mathrm{HCH})$}

$\mathrm{HCH}$ (also known as benzene hexachloride, BHC) is a mixture of five 1,2,3,4,5,6-hexachlorocyclohexane isomers that was formerly used extensively on cotton and other crops. Technical HCH use in the United States was curtailed in the late 1970s, but it remained in use elsewhere into the 
1990s ( $\mathrm{Li}$ et al. 1996). The purified $\gamma$-isomer (lindane), which also contains small amounts of the other isomers, is still used in North America for a few agricultural and domestic applications (Li et al. 1996; Poissant and Koprivnjak 1996). The 1995 samples were analyzed for four $\mathrm{HCH}$ isomers $(\alpha, \beta, \gamma$, and $\delta)$, but no residues were detected (Table 2). $\mathrm{HCH}$ isomers are comparatively volatile and rapidly cleared by fish (Butte et al. 1991; Willett et al. 1998). Residues occurred infrequently and at low concentrations in NCBP fish samples, and both incidence and concentrations of the two isomers measured historically $(\alpha$ and $\gamma$ ) were declining through the mid-1980s (Schmitt et al. 1999c).

\section{Mirex}

Mirex is a highly recalcitrant compound used historically as a fire retardant and as an insecticide to control red imported fire ants (Solenopsis invicta) in the South (Kaiser 1987). The historic distribution of mirex in NCBP samples reflected these patterns: residues greater than trace concentrations were found only at sites in the South, from insecticidal use; and in the Great Lakes basin, from point-source discharges (Kaiser 1987; Schmitt et al. 1990, 1999c). Concentrations in fish from both areas had been declining through 1986 (Schmitt et al. 1999c). In 1995, mirex was detected $(\geq 0.01 \mu \mathrm{g} / \mathrm{g})$ in only four samples $(4 \%)$ from two sites (4\%, Table 2) in LouisianaNCBP Station 81 (Red R. at Alexandria) and NAWQA Station 204 (Tensas R. at Tenda), the latter in the MSE Study Unit (data not shown). In 1986, traces of mirex were also present in fish from NCBP Stations 25 (Tennessee R. at Clarksville, TN) and 69 (Ohio R. at Cincinnati) at concentrations of 0.02-0.075 $\mu \mathrm{g} / \mathrm{g}$. Concentrations at Station 81 were $0.02-0.04 \mu \mathrm{g} / \mathrm{g}$ in 1995, slightly higher than they were in $1986(0.01-0.02 \mu \mathrm{g} / \mathrm{g})$; however, different species were collected in 1995 (carp and largemouth bass) than in 1986 (channel catfish and white bass). At stations with taxa common to both the 1986 and 1995 collections, mirex concentrations changed little (data not shown). Eisler (1985) stated that sensitive wildlife species are affected at dietary mirex levels of $0.1 \mu \mathrm{g} / \mathrm{g}$, a level that was approached but not exceeded by any sample collected in 1995 (Table 2). In laboratory-exposed freshwater fish, toxic effects have been observed at concentrations $\geq 0.35 \mu \mathrm{g} / \mathrm{g}$ (Jarvinen and Ankley 1999), and the NYSDEC wildlife guideline is 0.33 $\mu \mathrm{g} / \mathrm{g}$ (Newell et al. 1987), both of which are about eightfold greater than the highest 1995 concentrations.

\section{Hexachlorobenzene (HCB)}

Hexachlorobenzene (HCB) is virtually ubiquitous (Zell and Ballschmiter 1980). Environmental residues occur from the use of HCB a fungicide (Vizethum and Goerz 1979) and because $\mathrm{HCB}$ is a by-product of the production of other chlorinated hydrocarbons (Villanueva et al. 1974). HCB is shorter-lived (Villanueva et al. 1974) and much less toxic (Jarvinen and Ankley 1999) than DDT and most other persistent organochlorine compounds; however, commercial formulations once contained toxic impurities, including polychlorinated dibenzo- $p$ - dioxins and -dibenzofurans (Villanueva et al. 1974). In addition, HCB has a low level of dioxin-like activity (about 0.0001-0.001 relative to 2,3,7,8-TCDD-Hahn et al. 1996; Sinclair et al. 1997), and may therefore contribute to toxicity in combination with other polyhalogenated hydrocarbons. In 1995, HCB residues were detected (about $0.01 \mu \mathrm{g} / \mathrm{g}$ ) in only four samples (2\%) from three sites (7\%, Table 2): NCBP Stations 24 (Ohio R. at Marietta, OH), 76 (Mississippi R. at Memphis), and 23 (Kanawha R. at Nitro, WV). Concentrations in these samples were $0.020-0.075 \mu \mathrm{g} / \mathrm{g}$ (data not shown), which are at least 10-fold lower than Canadian wildlife guidelines (Environment Canada 1999). In 1986, traces $(<0.02$ $\mu \mathrm{g} / \mathrm{g}$ ) of HCB were also present in fish from NCBP Stations 15 (Mississippi R. at Luling, LA), 81 (Red R. at Alexandria, LA) and 69 (Ohio R. at Cincinnati, which was not sampled in 1995) but not at the three sites where was detected in 1995 .

\section{PCBs}

PCBs were used in a wide variety of commercial and industrial applications (Hutzinger et al. 1974). In 1995, residues in fish continued a downward trend in concentration and occurrence evident since the early $1980 \mathrm{~s}$; PCBs were detected $(\geq 0.05$ $\mu \mathrm{g} / \mathrm{g}$ ) in only $21 \%$ of the samples from $35 \%$ of the stations (Table 2), and none were detected in any samples from the reference site (Figure 7). In 1986 PCBs were detected at $65 \%$ of the NCBP stations nationwide and at 25 of the 34 NCBP stations (73\%) sampled in 1995 (Schmitt et al. 1999c). PCBs were also detected in 1984 at Station 90, which was not sampled in 1986 (Schmitt et al. 1990). In 1986, PCBs were not detected in any samples from Stations 30 (White R.), 32 (Missouri R. at Garrison Dam), 74 (Mississippi R. at Little Falls, MN), 77 (Arkansas R. at John Martin Res.), 78 (Verdigris R.), 84 (Big Horn R.), 85 (Yellowstone R.), 86 (James R.), or 88 (S. Platte R. at L. McConaughy, NE, which was not sampled in 1995), nor were any detected at most of these stations in 1995; traces were present in samples from Stations 30 and 86, however. From 1976-84, PCBs were present at about $91 \%$ of the NCBP stations nationwide (Schmitt et al. 1990). It should be noted that the declining incidence of PCBs in the MRB from 1984-86 to 1995 occurred despite the lower LOD for total PCBs in $1995(0.05 \mu \mathrm{g} / \mathrm{g})$ than in 1984-86 (0.1 $\mu \mathrm{g} / \mathrm{g})$; however, GC-ECD-based analyses of weathered PCBs based on Aroclor mixtures can vary considerably (Schwartz et al. 1987; Eganhouse and Gossett 1991), and the quantitation method used for the 1995 samples differed slightly from that used in 1984-86 (Schmitt et al. 1990).

Within the MRB, greatest 1995 PCB concentrations occurred at stations in the OHR and UMS subbasins, as they did in the past, and lowest levels were in the EIB and MSE Study Units (Figure 7). The values in carp from the EIB sites $(\leq 0.12$ $\mu \mathrm{g} / \mathrm{g}$ ) were slightly lower than those reported by Roberts (1997) for some EIB carp and by Tate and Heiny (1996) for carp from some sites in the Platte River system, differences possibly attributable to differing analytical methods. Concentrations of $1.0-3.2 \mu \mathrm{g} / \mathrm{g}$ in individual 1995 samples and station means $>0.3 \mu \mathrm{g} / \mathrm{g}$ occurred at NCBP Stations 24 (Ohio R. at Marietta, OH), 23 (Kanawha R. at Nitro, WV), 67 (Allegheny R.), 76 (Mississippi R. at Memphis), 111 (Mis- 


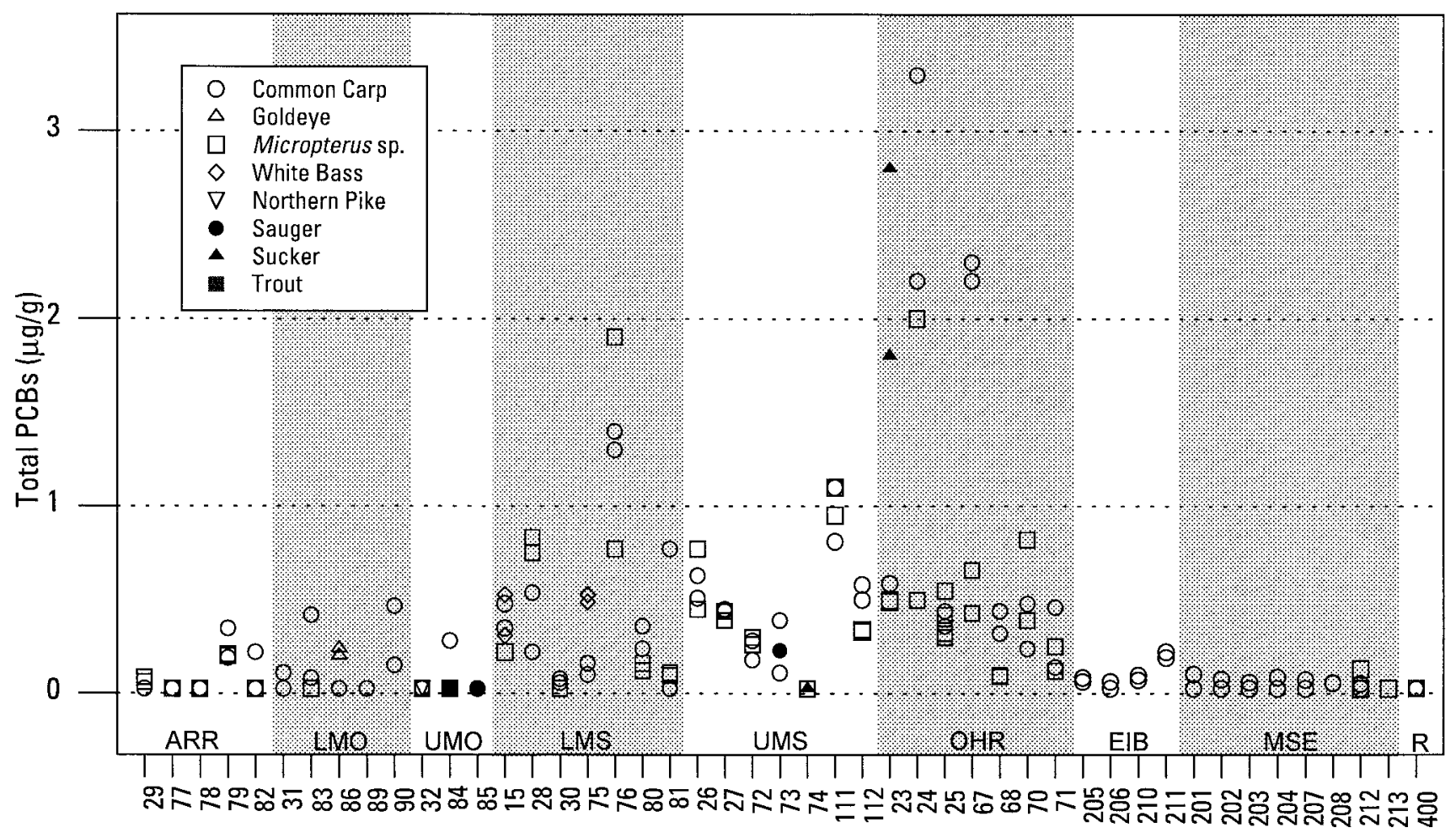

\section{Sub-basin and Station}

Fig. 7. Concentrations of total PCBs in composite samples of whole fish, by station, subbasin, and taxon. Censored values are plotted as 0.025 $\mu \mathrm{g} / \mathrm{g}$ (50\% LOD). See Table 1 for station locations and subbasins

sissippi R. at Lake City, MN), 26 (Illinois R.), 28 (Arkansas R.), 70 (Ohio R. at Metropolis, IL), 27 (Mississippi R. at Guttenburg, IA), 112 (Mississippi R. at Dubuque, IA), 25 (Cumberland R. at Clarksville, TN), and 15 (Mississippi R. at Luling, LA; Figure 7). At most of these sites, mean concentrations either declined substantially (Stations 23,81, 111, and 24) or did not change appreciably since the mid-1980s (Schmitt et al. 1999c; Zajicek et al. 2000; data not shown). Lee and Anderson (1998) also reported declining PCB concentrations in carp and walleye from urbanized areas of the MRB in Minnesota during 1975-95. Total PCB concentrations increased slightly at Stations 112, 28, and 76, however. Although there was a change in the species collected at some of these sites from 1986 to 1995 (especially at Station 28, where channel catfish and white crappie were replace by carp and largemouth bass; and at Station 76, as already noted), at the other sites at least one species was common to both collections. In withintaxon comparisons, total PCB concentrations in carp increased at Stations 75 (Mississippi R. at Cape Girardeau, MO), 70 (Ohio R. at Metropolis, IL), 111 (Mississippi R. at Lake City, MN), and 67 (Allegheny R.; data not shown). Concentrations declined in carp at Station 112 (Mississippi R. at Dubuque, IA) and in spotted bass at Station 25 (Cumberland $\mathrm{R}$. at Clarksville, $\mathrm{TN}$ ).

The New York wildlife guideline for total PCBs in fish is $0.11 \mu \mathrm{g} / \mathrm{g}$ (Newell et al. 1987), a concentration exceeded by at least one sample from Stations 76, 23, 24, and 67 (Figure 7). However, the toxicity of individual PCB congeners ranges over several orders of magnitude (Ahlborg et al. 1994; van den Berg et al. 1998) and varies with the endpoint being considered (Hansen 1998). The congener composition of weathered PCBs also varies greatly among NCBP locations and taxa (Zajicek et al. 2000). Toxicity of PCB congeners and other dioxin-like compounds occurs through multiple mechanisms, both aryl hydrocarbon hydroxylase $(\mathrm{AhR})$ and non-AhR-mediated. In addition, there are profound differences among taxa with respect to the uptake and metabolism of PCB congeners. Carp (especially) accumulate lower-chlorinated congeners that may exhibit thyroid-, neuro-, or endocrine-mediated toxicity (Gerstenberger et al. 1997). Therefore, the ecological risk represented by PCB residues in the 1995 fish samples is unknown.

\section{Summary and Conclusions}

With few exceptions, organochlorine chemical residues were detected at fewer stations and at lower concentrations in 1995 than at any time since monitoring began in the mid-1960s. Residues derived from DDT (primarily as $p, p^{\prime}$-DDE) were detected at all stations sampled (including the reference site), but potentially toxic (to fish-eating wildlife) concentrations ( $>1.0 \mu \mathrm{g} / \mathrm{g}$ ) were found only in the MSE NAWQA Study Unit, where the greatest concentrations occurred; and in the Yazoo River in Mississippi, where concentrations were elevated historically. These sites are all in the Lower Mississippi 
valley and drain watersheds farmed extensively for cotton. However, even at these sites little or no $p, p^{\prime}$-DDT was detected, indicating the continued weathering of residual DDT rather than the input of new material. Concentrations of DDT were also low at NCBP stations on the Arkansans and Tennessee Rivers that were historically influenced by point sources of contamination. Disproportionately high concentrations of $o, p^{\prime}-$ DDT homologs and traces of $p, p^{\prime}$-DDT in fish from one site (Ohio R. at Marietta, $\mathrm{OH}$ ) suggests more recent inputs, however. Toxaphene was also present only at sites in the Lower Mississippi valley. Because of the historically heavy use of DDT and toxaphene on cotton, average concentrations were greatest in the LMS subbasin and MSE Study Unit. Traces of mirex, which was used primarily in the South against red imported fire ants, were detected at only two sites in Louisiana.

Cyclodiene pesticide residues were detected at fewer stations (70\%) than DDT, but relatively high concentrations were more widespread. Although lower than levels reported in the past, relatively high concentrations of one or more cyclodiene residues (dieldrin, endrin, and chlordane-heptachlor) were present at sites in all subbasins except the ARR and UMO. Concentrations were generally highest in the EIB Study Unit and at most of the NCBP sites draining the cotton- and corn-producing regions of the central MRB, which encompasses parts of the UMS, LMS, OHR, and LMO subbasins. Cyclodiene pesticide concentrations were especially high in fish from the Mississippi River at Memphis, TN, where there are several point sources and where levels have been high in the past. Concentrations of all other organochlorine pesticides were very low.

PCB residues were detected at only $35 \%$ of the stations sampled and concentrations were generally low. Levels $>1.0$ $\mu \mathrm{g} / \mathrm{g}$ occurred only in fish from three sites in the OHR subbasin and from one each in the UMS and LMS subbasins, where mean concentrations were also greatest. PCB concentrations were generally lowest in the NAWQA Study Units (EIB and MSE), which drain primarily agricultural areas, and greatest at the NCBP stations near industrial and urban areas. Traces of $\mathrm{HCB}$ were detected at only two sites in the industrialized OHR sub-basin and in the Mississippi River at Memphis, TN.

The 1995 results confirm the continued weathering and redistribution of many organochlorine chemicals. Results from the MSE and EIB Study Units nevertheless indicate that considerable amounts of persistent pesticides remain in intensively farmed parts of the MRB and near point sources, from which they are available for transport and remobilization in aquatic ecosystems and where they may represent a continuing threat to terrestrial wildlife.

Acknowledgments. The information reported here was part of a pilot study designed to field-test and validate chemical and biological markers for use in the Biomonitoring of Environmental Status and Trends (BEST) program of the U.S. Geological Survey (USGS). The study was conducted in partnership with the U.S. FWS Division of Environmental Contaminants and the USGS National Water Quality Assessment program. Field portions of the study were conducted under the supervision of FWS Environmental Contaminants Specialists and USGS-NAWQA biologists stationed throughout the MRB. Laboratory analyses were conducted by the Mississippi State Chemical Labora- tory (MSCL) through a contract managed by the FWS Patuxent Analytical Control Facility (PACF) in Laurel, MD; C. Lusk of MSCL and J. Moore of PACF were especially helpful. Fish from the reference site were collected by personnel of the USGS Leetown Science Center in Kearneysville, WV. D. Tillitt, T. Kubiak, R. DeWeese, S. Smith, W. Bryant, T. Bartish, P. Anderson, V. Blazer, T. Gross, N. Denslow, J. Moore, P. MacDonald, M. Chandramoulesswaran, B. Wright, R. Jung, R. Lipkin, S. Finger, G. Dethloff, D. Nicks, and A. Donahue assisted with various aspects of the study. J. Zajicek, M. Mora, D. Tillitt, J. Whyte, and P. Capel reviewed an earlier version of this paper. Two anonymous reviewers provided numerous helpful suggestions.

\section{References}

Aguillar A (1984) Relationships of DDE/DDT in marine mammals to the chronology of DDT input into the ecosystem. Can J Fish Aquat Sci 21:840-844

Ahlborg UG, Becking GC, Birnbaum LS, Brouwer A, Derks HJ, Feeley M, Golor G, Hanberg A, Larsen JC, Liem AK, Safe SH, Schlatter C, Waern F, Younes M, Yrjnheikki E (1994) Toxic equivalency factors for dioxin-like PCBs. Chemosphere 28:10491067

Anderson DW, Jehl JR Jr, Risebrough RW, Woods LA Jr, DeWeese LR, Edgecomb WG (1975) Brown pelicans: improved reproduction off the southern California coast. Science 190:806-808

BEST (Biomonitoring of Environmental Status and Trends Program) (1996) Summary report from a workshop on selection of tier 1 bioassessment methods. U.S. Department of the Interior, National Biological Service, Washington, DC, Information and Technology Report 7, $55 \mathrm{p}$

Bidleman TF, Wall MD, Muir DCG, Stern GA (1993) Selective accumulation of polychlorocamphenes in aquatic biota from the Canadian arctic. Environ Toxicol Chem 12:701-710

Biglane KE, Tarzwell CM, Mount DI, Schaefer M, Breidenbach AW, Grzenda AR, Kittrell FW (1964) Report on pollution of the lower Mississippi River: Arkansas, Tennessee, Mississippi, Louisiana. Public Health Service, Washington, DC, 119 pp

Blazer VS, Dethloff GM (2000) Immune system indicators. In: Schmitt CJ, Dethloff GM (eds) Biomonitoring of Environmental Status and Trends (BEST) Program: selected methods for monitoring chemical contaminants in aquatic ecosystems. US Geological Survey. Biological Resources Division, Columbia, MO, Information and Technology Report USGS/BRD/ITR-20000005, pp 25-30

Blus LJ (1996) DDT, DDD, and DDE in birds. In: Beyer WN, Heinz GH, Redmon-Norwood AW (eds) Environmental contaminants in wildlife: interpreting tissue concentrations. Lewis Publishers, Boca Raton, FL, pp 49-71

Butte W, Fox K, Zauke G-P (1991) Kinetics of bioaccumulation and clearance of isomeric hexachlorcyclohexanes. Sci Tot Environ 109/110:377-382

CEQ (Council on Environmental Quality, US) (1997) Sustainable development in the U.S.: an experimental set of indicators. Interim Report. CEQ, Interagency Sustainable Development Indicators Working Group, Washington, DC

Colborn T (1991) Epidemiology of Great Lakes bald eagles. J Toxicol Environ Health 33:395-453

Colborn T, vom Saal FS, Soto AM (1993) Developmental effects of endocrine-disrupting chemicals in wildlife and humans. Environ Health Perspect 101:378-384

Crawford JK, Luoma SN (1992) Guidelines for studies of contaminants in biological tissues for the National Water-Quality Assessment Program. US Geological Survey, Reston, VA, Open-File Report 92-494, 69 pp

Eganhouse RP, Gosset RW (1991) Sources and magnitude of bias 
associated with determination of polychlorinated biphenyls in environmental samples. Anal Chem 63:2130-2137

Eisler R (1985) Mirex hazards to fish, wildlife, and invertebrates: a synoptic review. US Fish and Wildlife Service, Washington, DC, Biol Rep 85 (1.1)

Eisler R (1990) Chlordane hazards to fish, wildlife, and invertebrates: a synoptic review. US Fish and Wildlife Service, Washington, DC, Biol Rep 85(1.21)

Ellis GS, Huckins JN, Rostad CE, Schmitt CJ, Petty JD, McCarthy P (1995) Evaluation of lipid-containing semipermeable membrane devices and gas chromatography-negative chemical ionizationmass spectrometry for monitoring organochlorine chemical residues in large rivers. Environ Toxicol Chem 14:1875-1884

Environment Canada (1999) Canadian tissue residue guidelines for the protection of wildlife consumers of aquatic biota: summary table. In: Canadian tissue residue guidelines. Canadian Council of Ministers of the Environment, Water Quality Guidelines Task Group, Winnipeg, Manitoba (available online at www.ec.gc.ca/ceqg-rcqe)

Gerstenberger SL, Gallinat MP, Dellinger JA (1997) Polychlorinated biphenyl congeners and selected organochlorines in Lake Superior fish. Environ Toxicol Chem 16:2222-2228

Gooch JW, Matsamura F (1987) Toxicity of chlorinated bornane (toxaphene) residues isolated from Great Lakes lake trout (Salvelinus namaycush). Arch Environ Contam Toxicol 16:349-355

Goolsby D (1996) NASQAN II, redesign plan for the National Stream Quantity Accounting Network (draft). US Geological Survey, Water Resources Division, Reston, VA, pp 30-60

Goolsby DA, Battaglin WA, Thurman EM (1993) Occurrence, distribution, and transport of agricultural chemicals in the Mississippi River basin, July through August 1993. US Geological Survey, Reston, VA, Circular 1120-C, 22 pp

Grant BF (1976) Endrin toxicity and distribution in freshwater: a review. Bull Environ Contam Toxicol 15:283-290

Gundersen DT, Miller R, Mischler A, Elpers K, Mims SD, Millar JG, Blazer V (2000) Biomarker response and health of polychlorinated biphenyl and chlordane-contaminated paddlefish from the Ohio River Basin, USA. Environ Toxicol Chem 19:2275-2285

Hahn ME, Woodward BL, Stegeman JJ, Kennedy SW (1996) Rapid assessment of induced cytochrome $\mathrm{P} 4501 \mathrm{~A}$ protein and catalytic activity in fish hepatoma cells grown in multiwell plates: response to TCDD, TCDF, and two planar PCBs. Environ Toxicol Chem 15:582-591

Hansen LG (1998) Stepping backward to improve assessment of PCB congener toxicities. Environ Health Perspect 106:171-189

Harder HW, Carter T, Bidleman TF (1983) Acute effects of toxaphene and its sediment-degraded products on estuarine fish. Can J Fish Aquat Sci 40:2119-2125

Hirsch RM, Alley M, Wilber WG (1988) Concepts for a National Water-Quality Assessment Program. US Geological Survey, Reston, VA, Circular 1021, $42 \mathrm{pp}$

Hutzinger O, Safe S, Zitko V (1974) The chemistry of PCBs. CRC Press, Cleveland, OH, 269 pp

Jarvinen AW, Ankley GT (1999) Linkage of effects to tissue residues: development of a comprehensive database for aquatic organisms exposed to inorganic and organic chemicals. SETAC Press, Pensacola, FL, 358 pp

Johnson RE, Carver TD, Dustman EH (1967) Indicator species near top of food chain chosen for assessment of pesticide base levels in fish and wildlife-clams, oysters, and sediment chosen for estuaries. Pestic Monit J 1:7-13

Johnson WL, Finley MT (1980) Handbook of acute toxicity of chemicals to fish and aquatic invertebrates: summaries of toxicity tests conducted at Columbia National Fisheries Research Lab, 196578. US Fish and Wildlife Service, Washington, DC, 98 pp

Kaiser KLE (1987) The rise and fall of mirex. Environ Sci Technol $12: 520-528$

Kalkhoff SJ, Savoca ME, Tobias JL, Sadorf EM, Birkenholtz TL
(1994) National Water-Quality Assessment Program-Eastern Iowa Basins. US Geological Survey, Iowa City, IA, Fact Sheet 94-031, 2 pp

Krock B, Vetter W, Luckas B (1997) PCB/toxaphene separation on silica prior to congener specific determination of toxaphene residues in fish and other samples by GC/ECD. Chemosphere 35: $1519-1530$

Lee KE, Anderson JP (1998) Water quality assessment of the Upper Mississippi River Basin, Minnesota and Wisconsin-polychlorinated biphenyls in common carp and walleye fillets, 1975-95. US Geological Survey, Mounds View, MN, Water-Resources Investigations Report 98-4126, 27 pp

Leppanen CJ, Blanner PM, Allan RS, Benson WS, Maier KJ (1998) Using a triad approach in the assessment of hazardous waste site leaching from a Superfund site to an adjacent stream. Environ Toxicol Chem 17:2106-2113

Li Y-F, McMillan A, Scholtz MT (1996) Global HCH usage with $1^{\circ}$ $\times 1^{\circ}$ longitude/latitude resolution. Environ Sci Technol 30:35253533

Mallory MJ (1994) National Water-Quality Assessment Program-the Mississippi Embayment. US Geological Survey, Jackson, MS, Fact Sheet 94-047, 2 pp

Meade RH (1995) Contaminants in the Mississippi River, 1987-92. US Geological Survey, Denver, CO, Circular 1133, 140 pp

Messer JJ, Linthurst RA, Overton WS (1991) An EPA program for monitoring ecological status and trends. Environ Monit Assess 17:67-78

Muir DCG, de Boer J (1993) Toxaphene: analytical chemistry. Chemosphere 27:1827- 1834

Muir D, Braune B, DeMarch D, Norstrom R, Wagemann R, Lockhart L, Hargrave B, Bright D, Addison R, Payne J, Reimer K (1999) Spatial and temporal trends and effects of contaminants in the Canadian Arctic marine ecosystem: a review. Sci Total Environ 230:83-144

NRCC (National Research Council of Canada) (1974) Chlordane: its effects of Canadian ecosystems and its chemistry. Associated Committee on Scientific Criteria for Environmental Quality, Subcommittee on Pesticides and Related Compounds, Ottawa, Ontario, Subcommittee Rep No 2, NRCC No. 14094, 189 pp

Newell AJ, Johnson DW, Allen LK (1987) Niagara River biota contamination project: fish flesh criteria for piscivorous wildlife. New York Department of Environmental Conservation, Division of Fish and Wildlife, Bureau of Environmental Protection, Albany, Technical Report 87-3, 182 pp

Nowell LH, Capel PD, and Dileanis PD (1999) Pesticides in stream sediment and aquatic biota. Distribution, trends, and governing factors. Lewis Publishers, Boca Raton, FL, 1001 pp

Peakall DB (1996) Dieldrin and other cyclodiene pesticides in wildlife. In: Beyer WN, Heinz GH, Redmon-Norwood AW (eds) Environmental contaminants in wildlife: interpreting tissue concentrations. Lewis Publishers, Boca Raton, FL, pp 73-97

Poissant L, Koprivnjak J-F (1996) Fate and atmospheric concentrations of $\alpha$ - and $\gamma$-hexachlorcyclohexane in Quebec, Canada. Environ Sci Technol 30:845-851

Ribick MA, Dubay GR, Petty JD, Stalling DL, Schmitt CJ (1982) Toxaphene residues in fish: identification, quantification, and confirmation at part per billion levels. Environ Sci Technol 16:310318

Roberts LR (1997) Occurrence of selected organochlorine compounds in fish tissue from Eastern Iowa streams, 1995. US Geological Survey, Iowa City, IA, Fact Sheet 027-91, 4 pp

Rostad CE (1997) From the 1988 drought to the 1993 flood: transport of halogenated organic compounds with the Mississippi River suspended sediment at Thebes, Illinois. Environ Sci Technol 31: $1308-1312$

Schmitt CJ, Bunck CM (1995) Persistent environmental contaminants in fish and wildlife. In: LaRoe ET, Farris GS, Puckett CE, Doran 
PD, Mac MJ (eds) Our living resources: a report to the nation on the distribution, abundance, and health of US plants, animals, and ecosystems. National Biological Service, Washington, DC, p 413

Schmitt CJ, Dethloff GM (2000) Biomonitoring of Environmental Status and Trends (BEST) Program: selected methods for monitoring chemical contaminants in aquatic ecosystems. US Geological Survey, Biological Resources Division, Columbia, MO, Information and Technology Report USGS/BRD/ITR - 2000-0005, $81 \mathrm{pp}$

Schmitt CJ, Bartish TM, Blazer VS, Gross TS, Tillitt DE, Bryant WL, DeWeese LR (1999a). Biomonitoring of Environmental Status and Trends (BEST) Program: contaminants and their effects in fish from the Mississippi, Columbia, and Rio Grande basins. In: Morganwalp DW, Buxton HT (eds) US Geological Survey Toxic Substances Hydrology Program-Proceedings of the technical meeting, Charleston, SC, March 8-12, 1999, Volume 2 of 3-Contamination of hydrologic systems and related ecosystems. US Geological Survey, West Trenton, NJ, Water Resources Investigations Report 99-4018B, p 437

Schmitt, CJ, Blazer VS, Dethloff GM, Tillitt DE, Gross TS, Bryant WL Jr, DeWeese LR, Smith SB, Goede RW, Bartish TM, Kubiak TJ (1999b) Biomonitoring of Environmental Status and Trends (BEST) Program: field procedures for assessing the exposure of fish to environmental contaminants. US Geological Survey, Columbia, MO, Information and Technology Report USGS/BRD1999-0007, 35 pp

Schmitt CJ, Zajicek JL, May TW, Cowman DF (1999c) Organochlorine residues and elemental contaminants in US freshwater fish, 1976-1986: National Contaminant Biomonitoring Program. Rev Environ Contam Toxicol 162:43-104

Schmitt CJ, Ludke JL, Walsh D (1981) Organochlorine residues in fish, 1970-1974: National Pesticide Monitoring Program. Pestic Monit J 14:136-206.

Schmitt CJ, Ribick MA, Ludke JL, May TW (1983) National Pesticide Monitoring Program: organochlorine residues in freshwater fish, 1976-1979. US Fish and Wildlife Service, Washington, DC, Resource Publication 152, $62 \mathrm{pp}$

Schmitt CJ, Zajicek JL, Peterman PL (1990) National Contaminant Biomonitoring Program: residues of organochlorine chemicals in freshwater fishes of the United States, 1976-1984. Arch Environ Contam Toxicol 19:748-782

Schmitt CJ, Zajicek JL, Ribick MA (1985) National Pesticide Monitoring Program: residues of organochlorine chemicals in freshwater fish, 1980-81. Arch Environ Contam Toxicol 14:225-260

Schnoor JL (1981) Fate and transport of dieldrin in Coralville Reservoir: residues in fish and water following a pesticide ban. Science 211:840-842

Schwartz TR, Stalling DL, Rice CL (1987) Are polychlorinated biphenyl residues adequately described by Aroclor mixtures? Isomer-specific principal components analysis of such residues in fish and turtles. Environ Sci Technol 21:72-76

Sinclair PR, Walton HS, Gorman N, Jacobs JM, Sinclair JF (1997) Multiple roles of polyhalogenated biphenyls in causing increases in cytochrome P450 and uroporphyrin accumulation in cultured hepatocytes. Toxicol Appl Pharmacol 147:171-179

Stansley W, Roscoe DE (1999) Chlordane poisoning of birds in New Jersey, USA. Environ Toxicol Chem 18:2095-2099

Sumpter JP, Jobling S, Tyler CR (1996) Oestrogenic substances in the aquatic environment and their potential impact on animals, particularly fish. In: Taylor EW (ed) Toxicology of aquatic pollution: physiological, molecular, and cellular approaches. Cambridge University Press, Cambridge, p 205
Tate CM, Heiny JS (1996) Organochlorine compounds in bed sediment and fish tissue in the South Platte River Basin, USA, 1992 1993. Arch Environ Contam Toxicol 30:62-78

Thurman EM, Goolsby DA, Meyer MT, Kolpin DW (1991) Herbicides in surface waters of the Midwestern United States-effects of the spring flush. Environ Sci Technol 25:1794-1796

Tillitt D, Ankley G, Giesy J, Ludwig J, Kurita-Matsuba H, Weseloh D, Ross P, Bishop C, Sileo L, Stromborg K, Larson J, Kubiak T (1992) Polychlorinated biphenyl residues and egg mortality in double-crested cormorants from the Great Lakes. Environ Toxicol Chem 11:1281-1288

Trefry JHS, Metz S, Trocine RP, Nelsen TA (1985) A decline in lead transport by the Mississippi River. Science 230:439-441

US EPA (US Environmental Protection Agency) (1980) Ambient water quality criteria for DDT. Washington, DC, EPA440/5-80038, $173 \mathrm{pp}$

US EPA (1982) Toxaphene, intent to cancel or restrict registrations of pesticide products containing toxaphene; denial of applications for registration of pesticides containing toxaphene; determination concluding the rebuttable presumption against registrations; availability of decision document. Fed Reg 47:53784-53793

US EPA (2000) Guidance for data quality assessment-practical methods for data analysis. Office of Environmental Information, Washington, DC, Report EPA/600/R-96/084, EPA QA/G-9, QA00 update

van den Berg M, Birnbaum L, Bosveld BTC, Brunström B, Cook B, Feeley M, Giesy JP, Hanberg A, Hasegawa R, Kennedy SW, Kubiak T, Larsen JC, Rolaf van Leeuwen FS, Dijien Liem AK, Nolt C, Peterson RE, Poellinger L, Safe S, Schrenk D., Tillitt D, Tysklind M, Younes M, Waern F, Zacherewski T (1998) Toxic equivalency factors (TEFs) for PCBs, PCDDs, PCDFs for humans and wildlife. Environ Health Perspect 106:775-792

Villanueva EC, Jennings RW, Burse VW, Kimbrough RD (1974) Evidence of chlorobenzo- $p$-dioxin and chlorodibenzofurans in hexachlorobenzene. Agric Food Chem 22:916-917

Vizethum W, Goerz G (1979) Induction of the hepatic microsomal and nuclear cytochrome P-450 system by hexachlorobenzene, pentachlorophenol and trichlorophenol. Chem Biol Interact 28:291-299

Wiemeyer SN (1996) Other organochlorine pesticides in birds. In: Beyer WN, Heinz GH, Redmon-Norwood AW (eds) Environmental contaminants in wildlife: interpreting tissue concentrations. Lewis Publishers, Boca Raton, FL, p 99

Willett KL, Ulrich EM, Hites RA (1998) Differential toxicity and environmental fates of hexachlorocyclohexane isomers. Environ Sci Technol 32:2197-2207

Wong CS, Capel PD, Nowell LH (2000) Organochlorine pesticides and PCBs in stream sediment and aquatic biota-initial results from the National Water-Quality Assessment Program, 1992-1995. US Geological Survey, Sacramento, CA, Water-Resources Investigations Report 00-4053, 88 pp

Yurawecz MP, Roach JAG (1978) Gas-liquid chromatographic determination of chlorinated norbornene derivations in fish. J Assoc Off Anal Chem 61:26-31

Zajicek JL, Tillitt DE, Schwartz TR, Schmitt CJ, Harrison RO (2000) Comparison of an enzyme-linked immunosorbent assay (ELISA) to gas chromatography (GC) - measurement of polychlorinated biphenyls (PCBs) in selected United States fish extracts. Chemosphere 40:539-548

Zell M, Ballschmiter K (1980) Baseline studies of the global pollution. II. Global occurrence of hexachlorobenzene (HCB) and polychlorocamphenes (toxaphene) (PCC) in biological samples. Fres Zeits Anal Chem 300:387-402 